\title{
SUCCESSOR LIABILITY IN BANKRUPTCY: SOME UNIFYING THEMES OF INTERTEMPORAL CREDITOR PRIORITIES CREATED BY RUNNING COVENANTS, PRODUCTS LIABILITY, AND TOXIC-WASTE CLEANUP
}

\author{
David Gray Carlson*
}

\section{INTRODUCTION}

The state creates property, and (consistent with due process of law) the state takes it away. This article will focus upon a type of property destruction-foreclosure-that is integrally related to creditor priorities both in and out of bankruptcy.

Foreclosure theory is understudied and underdeveloped. It is neglected particularly when unusual forms of property are involved, many types of which have only recently been invented. This article will concern itself specifically with the foreclosure of what I will call servitudes-personal obligations that are imposed upon the owners of encumbered items simply by virtue of their being in possession of these items. ${ }^{1}$ Servitudes are not mortgages or liens. The encumbered items are not necessarily collateral for debts of their owners. Rather, servitudes are strictly personal obligations that may be enforced as such against servitude-debtors only by the usual means of injunction or execution of money judgments. The servient property merely signals whom the plaintiff may sue to enforce a contractual or tort duty.

This article will discuss three kinds of servitudes. First, it will consider the contractually created servitude on land. Second, it will consider the recently created products-liability servitude that may impose on owners of factories

\footnotetext{
Copyright $\odot 1987$ by Law and Contemporary Problems

- Associate Professor of Law, Benjamin N. Cardozo School of Law, Yeshiva University. I would like to give special thanks to Stewart Sterk and Mark Roe for their assistance.

1. "Servitude" will have quite a broad meaning in this article. It will refer to the property interest created generally by successor liability. It will include not only contractually created duties that become binding on possessors of burdened land, but any other tort-related duties that may be imposed on a possessor of land or personal property. For example, since the buyer of land on which a nuisance (such as toxic wastes) is located will be liable for cleanup, the land in question is burdened with a servitude as the term is used in this article. Similarly, since the buyer of a factory will find itself liable to the tort creditors of its predecessor under somewhat narrower circumstances, that factory is also encumbered by a servitude. This article will address the extent to which any such servitudes should be foreclosed in bankruptcy.
} 
and other productive assets personal liability for injuries stemming from products that former owners produced. ${ }^{2}$ And third, it will consider the liability imposed on landowners by state and federal law for decontaminating land polluted by toxic waste. ${ }^{3}$

If the owner of the servient property is bankrupt, these servitudes create unusual economic consequences for general creditors. Without foreclosure, servitudes can result in transfers of wealth from present to future creditors. A solvent buyer of the encumbered property will discount the purchase price by the amount of the expected inherited personal liability, and to this extent, the recovery of present creditors will be diminished in bankruptcy; future creditors, however, will receive a full recovery from the buyer of the encumbered property.

Generally speaking, few commentators and even fewer courts have examined the intertemporal priorities created by such servitudes. ${ }^{4}$ After conducting such an examination, this article will consider the extent to which they can or should be changed in bankruptcy (or any other lien-enforcement procedure under state law) through the use of foreclosure rules. It concludes that, unless contradicted by some other important social goal, these servitudes should be foreclosable to prevent intertemporal inequality among creditors or the retirement of assets. ${ }^{5}$

2. Ray v. Alad Corp., 19 Cal. 3d 22, 560 P.2d 3, 136 Cal. Rptr. 574 (1977); see Mooney Aircraft v. Foster (In re Mooney Aircraft, Inc.), 730 F.2d 367, $371-72$ (5th Cir. 1984).

3. There are servitudes other than those discussed in this paper. For example, ERISA pension liability attaches to enterprises, and one can view this as a servitude. 26 U.S.C. $\$ 414$ (a) (1982); $R$. Osgood, The Law of Pensions and Profit Sharing $\$$ 9.1.1 (1984). Likewise, labor law recognizes a union contract servitude on enterprises. John Wiley \& Sons, Inc. v. Livingston, 376 U.S. 543, 550-51 (1964); Slicker, A Reconsideration of the Doctrine of Employer Successorship-A Step Toward a Rational Approach, 57 MinN. L. Rev. 1051 (1973); see Jackson, Translating Assets and Liabilities to the Bankruptcy Forum, 14 J. LEGAL STUd. 73, 97-98 (1985) (arguing that union contract servitudes should not be foreclosed in bankruptcy). I have arbitrarily excluded these servitudes from my discussion, but these other servitudes readily lend themselves to the same analyses deveioped in this article.

4. An important exception is Mark Roe, who has written on future tort creditors in bankruptcy proceedings and on the products-liability servitude outside the bankruptcy context. Roe, Bankruptcy and Mass Tort, 84 Colum. L. Rev. 846 (1984) [hereinafter Roe, Mass Tort]; Roe, Corporate Strategic Reaction to Mass Tort, 72 VA. L. Rev. 1 (1986); Roe, Mergers, Acquisitions, and Tort: Comment on the Problem of Successor Corporation Liability, 70 VA. L. REv. 1559 (1984) [hereinafter Roe, Successor Liability]. See also Green, Successor Liability: The Superionity of Statutory Reform to Protect Products Liability Claimants, 72 Cornell L. Rev. 17 (1986).

5. Intertemporal equality is a "weak" bankruptcy norm in the sense that conflicting norms will prevail from time to time. Roe, Mass Tort, supra note 4, at 865 .

The terms "present" and "future," as applied to claims, distinguish rather loosely between mature, accrued rights that can currently be enforced and rights that have not yet been violated but that could later give rise to a monetary demand. Future claims also include present claims that could be asserted against a future buyer of burdened property. Although it is a matter of much dispute, see infra text accompanying notes 117-25, I will assume that both "present" and "future" creditors can participate in a bankruptcy proceeding and that each has a currently calculable claim. In asserting that servitudes result in intertemporal inequality, I mean only that servitudes increase the percentage recovery of future creditors and decrease the percentage recovery of present creditors. 


\section{Secured and Unsecured Obligations}

A personal obligation entitles the obligee to enlist the aid of the state in forcing the obligor to pay a debt or perform some other duty. When the obligation is or can be expressed as a duty to pay money, the state enforces this duty by giving the debtor's assets to the creditor for the limited purpose of selling them and converting them into cash, which is used to pay the creditor's claim. At the moment the creditor receives a right to sell the debtor's assets (that is, a lien), the state makes him a secured creditor ${ }^{6}$ who must compete for priority with other secured creditors and holders of other property interests in these assets. ${ }^{7}$

A secured creditor has not only an enforceable personal claim against the debtor, ${ }^{8}$ but also a direct property interest in designated assets of the debtor. Whether a secured creditor has obtained his lien through the judicial process or by some nonjudicial means, the collectability of his claim ultimately depends upon a lien-enforcement system. Therefore, with emphasis on the function of foreclosure, a few words are necessary to describe the mechanics of such a system.

In order for a lien-enforcement system to work, the lien creditor must have something to sell that buyers are willing to buy. Otherwise, no cash could be generated to satisfy the underlying obligation. The lien-enforcement rules must be capable of terminating enough preexisting property interests to guarantee a prospective buyer of the asset title good enough to justify a bid. To this end, two minimum requirements must be met. First, the enforcing creditor's property interest must be foreclosed. A prospective buyer would never bid if the creditor could immediately relevy the asset.9 Second, the

6. In my view, a general creditor becomes a secured creditor "when the debtor's ability to transfer property to some third party transferee is first defeated." Carlson \& Shupack, Judicial Lien Priorities under Article 9 of the Uniform Commercial Code: Part I, 5 Cardozo L. REv. 287, 297 (1984) (emphasis in the original).

7. See generally id. at 288-90.

8. Of course, nonrecourse liens are possible. E.g., Vintero Corp. v. Corporacion Venezolana de Fomento, 735 F.2d 740, 742 (2d Cir.), cert. denied, - U.S. - 105 S. Ct. 592 (1984). In such a case, the creditor's rights are limited to proceeds of the sale of the encumbered property; no judgment against the property's owner is possible. Nonrecourse liens can arise where the parties have consensually excluded personal liability or where the owner has bought property without assuming personal liability on a preexisting encumbrance. Some courts view equitable servitudes on real estate as no more than nonrecourse liens. See infra note 27.

9. A brief explanation may help. If the encumbered property were worth $\$ 100,000$ and the secured claim being enforced were worth $\$ 10,000$, buyers willing to bid $\$ 10,000$ would gladly do so even if the creditor's lien on the property were not foreclosed. If the buyer paid $\$ 10,000$ for the property, the proceeds would be paid to the creditor, whose debt would be extinguished-as would be his lien-leaving the buyer free of any future interference from this quarter.

Foreclosure, as distinguished from extinction of debt, is significant in situations in which the secured claim exceeds the value of the encumbered property. For example, suppose that a lien creditor with a floating lien of $\$ 100,000$ on all the debtor's property forced a sale of $\$ 10,000$ worth of that property. Under these circumstances, buyers would never buy the property unless the creditor agreed to terminate his lien therein. Foreclosure of a lien, therefore, simply duplicates the terms to which the creditor would have to agree if he had any present desire to collect on property worth less than his secured claim. 
debtor's property interest must be foreclosed as well, for much the same reason. Unless he were immune from at least these two competing interests, no prospective buyer would bid at any enforcement sale. ${ }^{10}$

Beyond this, the lien-enforcement system can be rendered more effective for the enforcing creditor to the extent that other property interests in the asset are foreclosed as well, since a prospective buyer likely will be willing to pay more for a higher grade title. A common rule (although not one universally followed) is that the buyer at a foreclosure sale takes whatever interest the debtor had in the asset at the time the creditor's lien arose. Such a description of the buyer's title implies that the property interests not only of the debtor, but also of the debtor's postlien transferees, are foreclosed by the sale of the asset. This rule prevents the debtor from defeating the enforcing creditor with possible eleventh-hour presale conveyances of the asset. Under such a foreclosure rule, any postlien transferee from the debtor can be said to have received no more than what the debtor had: a property interest subject to foreclosure at a lien-enforcement sale.

Sometimes, the property interests of prelien transferees may be foreclosed. For example, buyers at foreclosure sales may take free of some preexisting but unperfected real estate conveyances or article 9 security interests. Moreover, a lien creditor can sometimes compel the debtor's prelien transferees to accept cash in exchange for the foreclosure of their property interests. Thus, the Internal Revenue Service, when it forecloses a tax lien, has a prodigious ability under a recent Supreme Court decision ${ }^{11}$ to foreclose earlier created property interests. For the most part, however, lien creditors cannot foreclose the property interests of the debtor's prelien transferees. The rationale is clear enough when the prelien transfer is a possessory or future interest. In such a case, there is a reluctance to compel a party to sell his property involuntarily; however, when the senior interest is only a lien, the rationale for protecting it against foreclosure is less obvious. ${ }^{12}$

Injunctive relief is often an alternative means of enforcing personal obligations to pay money. Injunctions do not have any necessary property consequences, but merely coerce payment on pain of imprisonment or exaction of a fine for contempt. If a debtor has no unencumbered assets, an injunction will be of no monetary value to a creditor. In recognition of this fact, innovative equity courts have bolstered their contempt powers with property concepts. Thus, a right to an injunction sometimes has been held to

10. For more on this "minimal theory of foreclosure," see Carlson, Death and Subordination under Article 9 of the Uniform Commercial Code: Senior Buyers and Senior Lien Creditors, 5 Cardozo L. Rev. 547, 565-71 (1984) [hereinafter Carlson, Death and Subordination]; Carlson, Simultaneous Attachment of Liens on After-Acquired Property, 6 Cardozo L. REv. 505, 508-10 (1985) [hereinafter Carlson, Simullaneous Attachment].

11. United States v. Rodgers, 461 U.S. 677 (1983).

12. For contrasting views on whether senior liens should be foreclosed in junior interest enforcement sales, see Carlson, Simultaneous Attachment, supra note 10, at 530-34 (senior liens should be foreclosed in junior sales); Frisch, The Priority Secured Party/Subordinated Lien Creditor Conflict: Is "Lien-Two" Out in the Cold?, 33 Buffalo L. Rev. 149, 163 (1984) (senior liens should not be foreclosed in junior sales). 
imply the existence of an equitable lien on specific property, which may frustrate a debtor's efforts to avoid his obligation by conveying the property to another. The equitable lien itself may enjoy a priority vis-a-vis competing liens, but the basic priority pattern applicable to judicial and consensual liens will still obtain. ${ }^{13}$

\section{III}

\section{SERVITUDES}

\section{A. Running Convenants and Equitable Servitudes on Land}

No area of the law quite matches the confusion and disarray posed by real covenants and equitable servitudes on land. ${ }^{14}$ I will pass over most of the doctrinal complexities, ${ }^{15}$ however, to draw only a few simple distinctions between personal obligations that do run with the land and those that do not run with the land.

Real covenants and equitable servitudes painfully crowbarred their way into the law to meet the need for land-use planning. The fundamental notion underlying these devices is that landowners need to control the conduct of their neighbors. If an obligation undertaken by a neighbor were purely personal, he could easily avoid it by sale of the land to strangers. ${ }^{16}$ By tying the obligation to possession of the land, however, a much greater likelihood of compliance is assured.

Courts seem quite suspicious of the running covenant and, therefore, require that it be demonstrably conducive to genuine land-use planning. For instance, covenants and servitudes must touch and concern the land;17 lack of vertical privity of estate can often invalidate a covenant; ${ }^{18}$ and servitudes may be terminated when they no longer increase land values. ${ }^{19}$ One possible

13. The basic priority rule is "first in time is first in right," but courts will not enforce equitable property interests when the encumbered property is in the hands of a bona fide purchaser for value. To the extent that a subsequent consensual lienor is a bona fide purchaser for value, he can establish his priority as against an earlier equitable lien. Subsequent judicial lien creditors are not purchasers for value, however, and if they are later in time, they will be subordinated to an equitable lien. But a buyer at a judicial lien enforcement sale may independently qualify as a bona fide purchaser for value; and if so, he may pay a price commensurate with his priority-that is, a price reflecting freedom from interference by the earlier equitable lien. See Carlson, Death and Subordination, supra note 10 , at $570-71$.

14. Readers should be alerted to a slight variation in usage of the word "servitude." When referring to contractually created duties that are imposed on landowners, this article will speak of "real covenants" to indicate obligations enforceable at law and "equitable servitudes" to indicate obligations enforceable in equity. Both, however, are "servitudes" as earlier defined. Supra note 1.

15. These complexities have been thoroughly reviewed recently in French, Toward a Modern Law of Servitudes: Reweaving the Ancient Strands, 55 S. CAL. L. REv. 1261 (1982); Reichman, Toward a Unified Concept of Servitudes, 55 S. CAL. L. REv. 1179 (1982); Sterk, Freedom from Freedom of Contract: The Enduring Value of Servitude Restrictions, 70 IOWA L. REV. 615 (1985).

16. Neponsit Property Owners' Ass'n v. Emigrant Savings Bank, 278 N.Y. 248, 254-55, 15 N.E.2d 793, 795 (1938); Sterk, supra note 15, at 617-18.

17. C. Clark, Real Covenants and Other Interests Which "Run with Land" 94, $96-100$ (2d ed. 1947).

18. It may not, however, invalidate an equitable servitude. Reichman, supra note 15, at 1249-52.

19. C. Clark, supra note 17 , at $184-85$. 
justification for the creation of these barriers is that while personal and secured obligations are foreclosable, running covenants and servitudes are not. In the absence of some method of discharge, unfortunate promises tied to the land can last indefinitely. ${ }^{20}$ With regard to the nature of the burdened landowner's obligation, however, we must distinguish between running covenants at law and purely equitable servitudes.

One of the mysterious cliches about real covenants is that, unlike equitable servitudes, they are not interests in the land itself. They run with the land, in Professor Powell's famous phrase, "like a bird on a wagon."21 What I think this means, in part, is that the land is not the collateral for the obligation, but simply signals who is personally liable. Accordingly, possession of the land takes the place of an express assumption of liability. ${ }^{22}$ For our purposes, this means that the plaintiff seeking damages for breach of the covenant must get a money judgment and seek to collect it out of the defendant's assets, assets that include the very land burdened by the covenant. Executing such a money judgment confers a lien that in no way differs from other judgment liens. ${ }^{23}$

Most covenants are also equitable servitudes, meaning that a plaintiff may have equitable remedies in addition to an enforceable money judgment. The most common of these equitable remedies is undoubtedly the injunction, which coerces the landowner to conform his conduct to the requirements of the servitude. ${ }^{24}$ Equity also may supply incidental damage awards, which can be enforced in the same manner as standard money judgments: by writs of execution and the like. ${ }^{25}$ To the extent that the remedy for breach of an obligation is a damage award, servitudes do not differ from covenants; but many courts have concluded that servitudes (especially servitudes requiring the payment of money) can also be enforced by equitable liens on the burdened property itself. ${ }^{26}$ Some courts have even intimated that

20. Richard Epstein has recently proposed that any contract promise should be eligible to be a running covenant even if unrelated to land-use planning. Epstein, Notice and Freedom of Contract in the Law of Servitudes, 55 S. CAL. L. Rev. 1353, 1354-58 (1982). He does not, however, deal with the fact that his plan would allow what are now secured transactions (foreclosable upon default) to become servitude transactions (in which the burden is not foreclosable). The problems created would not be insurmountable, but the bankruptcy rules pertaining to liens would have to be adapted to the resulting new type of secured transaction.

21. 5 R. Powell, Real Property 9 670[2] (P. Rohan ed. 1977).

22. Maine v. Cumston, 98 Mass. 317, 320 (1867). See also Georskey v. Wildflower Landholding Assocs. (In Re Wildflower Landholding Assocs.), 49 Bankr. 246, 249 (Bankr. M.D. Fla. 1985) (personal liability did not disappear just because the debtor had sold the burdened land).

23. Hoskins v. Walker, 255 S.W.2d 480, 481 (Ky. 1953) ("A person who violates a covenant ordinarily responds in damages in an action at law"). Professor Allison Dunham uses the unlimited personal liability of the landowner to explain why temporary or partial owners are not in vertical privity with the holder of the fee. Such "serious" liability should not be visited on temporary possessors. Dunham, Promises Respecting the Use of Land, 8 J. L. \& Econ. 133, 155-56 (1965).

24. E.g., Thodos v. Shirk, 248 Iowa 172, 79 N.W.2d 733 (1956).

25. 1 A. Freeman, a Treatise on the law of Executions in Civil Cases, and of Proceedings in Aid and Restraint Thereof $\$ 10$ (3d ed. 1900).

26. E.g., Child v. C.H. Winans Co., 183 A. 300, 303 (1936). At least one court has said it was imposing a lien to secure a covenant at law. In Mendrop v. Harrell, 233 Miss. 679, 692, 103 So. 2d 418, 424 (1958), the court observed: "Manifestly, it would be useless and ineffectual to create a covenant running with the land unless it also imposed on the property a lien for its enforcement. Nor is it necessary that the deed containing a covenant of this type expressly state that it shall 
enforcement of equitable liens is the only means by which damages can be recovered for breach of an equitable servitude. ${ }^{27}$ The priority of an equitable lien differs from that of a judicial lien stemming from a breach of covenant in that a judicial lien on land burdened by the covenant usually arises when the judgment is docketed, ${ }^{28}$ while an equitable lien relates back to some earlier time, frequently the time when the servitude was first placed on the land. ${ }^{29}$

Complicating the matter is the fact that equitable servitudes are often accompanied by consensual liens (that is, mortgages) on the burdened land securing the performance of the same obligation. A leading decision dealing with this type of arrangement is Neponsit Property Owners' Association v. Emigrant Industrial Savings Bank. ${ }^{30}$ In Neponsit a suburban development company,

constitute a lien." The problem with this area of the law is that the words and concepts are so confusing that one cannot confidently rely on the assumption that judges mean what they say. Indeed, the court here may have been talking only about equitable servitudes, not covenants at law. In any case, it is incorrect that servitudes without liens are useless and ineffectual. See infra text accompanying note 35 and notes 88-99.

27. For example, in Everett Factories \& Terminal Corp. v. Oldetyme Distillers Corp., 300 Mass. 499, 506-09, 15 N.E.2d 829, 834-35 (1938), the Supreme Judicial Court of Massachusetts determined that a monetary servitude could be recovered out of the burdened land only. It distinguished partywall cases, where the defendant personally used the maintained service and no limitation on personal recoveries had been set. See also Whittenton Mfg. Co. v. Staples, 164 Mass. 319, 328, 41 N.E. 441, 445 (1895) (money obligation "may be enforced as an obligation in the nature of a servitude upon the estate of the defendant, though not as a personal obligation of the defendant").

In University Gardens Property Owners Ass'n v. Steinberg, 40 Misc. 2d 816, 817-18, 244 N.Y.S.2d 208, 209-10 (Dist. Ct. 1963), the court only had jurisdiction over in personam-not in rem-matters; therefore, it had to address the theory stated in the text. The court concluded that servitudes did not give rise to personal obligations and that, accordingly, it lacked jurisdiction in the matter; but its conclusion was based solely on a rather unimaginative reading of Nicholson v. 300 Broadway Realty Corp., 7 N.Y.2d 240, 247, 164 N.E.2d 832, 836, 196 N.Y.S.2d 945, 950-51 (1959) ("If the defendant had merely taken conveyance of the property, without expressly assuming performance of the contractual duty owed ... to the plaintiffs ... the plaintiffs would have had no contractual claim against the defendant"). In fact, the language in Nicholson on which Steinberg relied deals only with whether the defendant had expressly assumed a contractual obligation and is completely unrelated to running covenants. See Maine v. Cumston, 98 Mass. 317, 319-20 (1867) (similar usage of same terms).

28. E.g., N.Y. Civ. Prac. L. \& R. § 5203(a) (McKinney 1978).

29. See Bessemer v. Gerston, 381 So. 2d 1344, 1347-48 (Fla. 1980). Although this case involved an express lien, the plaintiff faced a problem with regard to the defendant's homestead rights, which, under Florida law, had to yield to preexisting liens. The defendant argued that the consensual servitude lien could not have arisen before he took the property from the servitude lien creditor-a quite plausible claim -and that, in fact, the lien and the homestead rights had been simultaneously created. If so, the lien was not "preexisting." See Carlson, Simultaneous Attachment, supra note 10, at 516. The court, however, used a relation-back principle that determined the consensual lien's priority by reference to the date of creation of the servitude, which was well before the date of creation of the defendant's homestead rights. The exact moment of creation of the servitude was not as precisely identified as it might have been. I assume that when the developer conveyed a plat of land to a third party $(A)$, he simultaneously burdened the remaining land with a servitude enforceable by $A$ and secured by a lien. When, thereafter, the developer conveyed to the defendant, this "preexisting" lien overrode the defendant's homestead rights.

30. 278 N.Y. 248,15 N.E.2d 793 (1938). See also Leisuretowne Ass'n v. McCarthy, 193 N.J. Super. 494, 502, 475 A.2d 62, 66 (App. Div. 1984); Bessemer v. Gerston, 381 So. 2d 1344, 1348 (Fla. 1980); William W. Bond, Jr. \& Assoc. v. Lake O'the Hills Maintenance Ass'n, 381 So. 2d 1043, $1044-$ 45 (Miss. 1980). The two difficult issues in the Neponsit case are not really of prime concern to us, but deserve brief mention. First, the court had to determine whether the servitude, an obligation to pay money, "touched and concerned" the bank's land. The court ruled that it did, and hence the bank had a continuing obligation to pay. Second, the court was troubled by the New York rule that servitudes in gross do not run with the land. 278 N.Y. at 259-63, 15 N.E.2d at 797-98. The court 
wishing to finance and maintain community improvements by use of a private tax, required each homeowner in the development to burden his land with a servitude backed by a mortgage to secure the tax payment of four dollars per year. ${ }^{31}$ The development company then conveyed its enforcement rights to a homeowners' association. ${ }^{32}$

There is no reason why the personal obligation that inheres in a real convenant or equitable servitude should not be secured by a mortgage on the burdened land. Indeed, a consensually created servitude lien would merely duplicate the equitable lien that some courts have otherwise imposed. ${ }^{33}$ The utility of a lien that relates back to the creation of the servitude, be it consensual or equitable, lies in preserving the collateral against erosion by any subsequent liens. ${ }^{34}$ If a majority of contracting parties wants a lien that relates back in such a manner, finding an equitable lien by implication in all servitudes, absent evidence of contrary intent, may be justified as a means of reducing the transaction costs of creating servitudes. ${ }^{35}$

essentially pierced the corporate veil, however, noting that the association consisted of a class of landowners entitled to enforce the covenant.

31. 278 N.Y. at 253,15 N.E. $2 d$ at 794.

32. Id. at 260,15 N.E.2d at 797.

33. Equating consensual liens securing a servitude obligation with equitable liens that relate back to the time the servitude was created requires a brief exposition of the rules governing mortgages for future advances. Although mortgages typically secure contemporaneously extended loans, they may also secure loans to be given in the future. See generally Meek, Mortgage Provisions Extending the Lien to Future Advances and Antecedent Indebtedness, 26 ARK. L. REv. 423 (1973). When the parties agree to a future-advance clause in the mortgage, the priority of the lien for the future advance depends on whether the lender has commited himself to making the loan or has reserved discretion in the matter. Where the future advance is discretionary, each future advance gives rise to a new mortgage lien with its own distinctive priority. Where the future advance is made pursuant to a commitment to lend, however, the priority of the mortgage lien for any advance relates to the date of the commitment, regardless of the actual date of the advance. G. OSBORNE, HANDBook on tHE LAW of MORTGAGes $\S 120$ (2d ed. 1970); Comment, Mortgages to Secure Future Advances: Problems of Priority and the Doctrine of Economic Necessity, 46 Miss. L.J. 433 (1975). Since the owner of an equitable servitude or running covenant has either given or is committed to giving value, the mortgage to secure the commitment must be equated with a mortgage to secure a nondiscretionary future advance. Consequently, the priority of a servitude mortgage relates back to the time the servitude was created. This is precisely the result achieved when courts have declared that equitable servitudes give rise to equitable liens on the burdened land.

34. The statement in the text assumes that the servitude and any consensual lien are properly recorded.

35. As this article will discuss, equitable liens also help solve a vexatious priority problem when a senior servitude conflicts with a junior mortgage. See infra text accompanying notes 88-90.

Professor Dunham assumes that once an express lien exists for a renewable servitude obligation, it is no longer important whether the obligation runs with the land. Dunham, supra note 23, at 14748. This is so, however, only if the servitude lien cannot be foreclosed by other liens. Because tax liens sometimes have a superpriority that can foreclose even earlier liens, it is necessary that successor liability supplement the servitude lien to insure against the consequences of foreclosure.

Professor Russell Reno solemnly opposes imposition of a lien in covenant at law unless the grant expressly authorizes it. Reno, Covenants, Rents and Public Rights, in 2 American Law of Property $\$ 9.17$, at 387-88 (Casner ed. 1952). The basis of his opposition is not really stated, but it seems to flow from a formalist appreciation for the distinction between rights in personam and rights in rem. He takes no view on equitable liens to enforce equitable servitudes. 


\section{B. The Products-Liability Servitude}

In Ray v. Alad Corp. ${ }^{36}$ the California Supreme Court allowed a productsliability plaintiff to sue the owner of a factory that had produced a defective ladder long before the transfer of the factory to its current owners. Other major industrial states such as Pennsylvania, ${ }^{37}$ New Jersey, ${ }^{38}$ Wisconsin, ${ }^{39}$ and Michigan $^{40}$ have since followed suit.

The products-liability servitude is the culmination of a series of doctrinal exceptions to a general principle, each carried a step further to a final result that is far beyond the bounded set of rules that gave it birth. The point of departure was the notion that although a corporation is liable for the torts of its agents, its shareholders are not. Since it was logical to deduce that a merged entity would continue to be liable for the debts of each constituent corporation, ${ }^{41}$ corporate lawyers soon learned that by avoiding mergers and substituting sales of assets instead, the assets of a debtor might be laundered and its creditors' claims against the buyer effectively eliminated.

Fraudulent conveyance law helped curb the worst of these abuses by rendering the conveyed property available to the seller's creditors where the courts could be persuaded that the transaction was a disingenuous one. But if there was a legitimate transfer of assets for fair consideration, general creditors of the seller had no property interest in the conveyed assets, and the buyer inherited no personal liability along with the purchase of these assets.

Where the buyer paid for assets with stock and the seller quickly dissolved, courts learned to label the transaction a "de facto merger" 42 and again imposed personal liability on the buyer, reasoning that because the seller ended up as a shareholder of the buyer, the seller and buyer were essentially the same entity and subject to the same liabilities. But for some reason, courts were initially unwilling to extend this rule to asset sales in which the consideration was cash or items other than equity securities. ${ }^{43}$ The distinction between cash sale and merger was finally erased in Ray v. Alad Corp.

This case was born in the laundry room of UCLA in 1968, when Herbert C. Ray fell off a ladder and injured himself. ${ }^{44}$ Choosing to blame the ladder, Ray sued the manufacturer, only to find that the manufacturer had sold the business and dissolved. ${ }^{45}$ Ray then sued the new owner of the business, but the traditional doctrines on which he relied, such as "piercing the corporate veil" and de facto merger, could not be made to fit the situation at hand in

36. 19 Cal. 3d 22, 560 P.2d 3, 136 Cal. Rptr. 574 (1977).

37. Dawejko v. Jorgensen Steel Co., 290 Pa. Super. 15, 434 A.2d 106 (1981).

38. Ramirez v. Amsted Indus., Inc. 86 N.J. 332, 431 A.2d 811 (1981).

39. Tift v. Forage King Indus., Inc., 108 Wis. 2d 72, 322 N.W.2d 14 (1982).

40. Turner v. Bituminous Casualty Co., 397 Mich. 406, 244 N.W.2d 873 (1976).

41. Forest Laboratories, Inc. v. Pillsbury Co., 452 F.2d 621, 625 (7th Cir. 1971); Kloberdanz v. Joy Mfg. Co., 288 F. Supp. 817, 820 (D. Colo. 1968) (applying California law).

42. Note, Expanding the Products Liability of Successor Corporations, 27 HAstings L.J. 1305, 1313-19 (1976).

43. E.g., Ortiz v. South Bend Lathe, 46 Cal. App. 3d 842, 120 Cal. Rptr. 556 (1975).

44. 19 Cal. 3d at 25, 560 P.2d at 5, 136 Cal. Rptr. at 576.

45. Id. at 24-28, 560 P.2d at 4-7, 136 Cal. Rptr. at 575-578. 
which the seller had legitimately cashed out of the business. ${ }^{46}$ Undeterred, the court expanded the de facto merger concept: Certain assets would now be considered encumbered in favor of products-liability victims whose claims had not accrued in time to be asserted against the liquidating seller. ${ }^{47}$

In justifying this new departure, the court did not venture much beyond the observation that the buyer was a "deep pocket," 48 but the manner in which the court invoked the "deep pocket" rationale was interesting. Instead of pointing out that the buyer was probably rich and the victim probably poor, the court attempted an economic argument obviously cribbed from Calabresian literature on products liability: Where unavoidable accidents occur, manufacturers can protect themselves by raising prices to cover the increased cost of new liability; if companies are not liable for product defects, they can increase their profits by exporting these costs to the public. ${ }^{49}$

Although this rationale for products liability has come under attack on its own grounds, ${ }^{50}$ it is particularly inappropriate in the context of asset sales. Instead of defraying the cost of the additional products liability by raising prices, a buying company would probably respond by reducing its offering price for the seller's productive assets, the differential being the perceived face amount of future products liability, discounted to present value. ${ }^{51}$ The consequent reduction in value of the seller's estate would prejudice existing creditors where the seller was insolvent; indeed, existing creditors would be required to subsidize one hundred percent recoveries of future tort claimants, an inequality with which the California Supreme Court did not deal. ${ }^{52}$

Because the Alad rule is so potentially subversive of the cherished belief that general creditors have no direct property interests in the debtor's assets, it is important to assess just how courts have limited or will limit the productsliability servitude. First, the California Supreme Court emphasized strongly in Alad that only unmatured tort claimants may enjoy the benefit of the

46. Id. at 28, $560 \mathrm{P} .2 \mathrm{~d}$ at 7, $136 \mathrm{Cal}$. Rptr. at 578 .

47. Id. at 33 n.6, 34, 560 P.2d at 10 n.6, 11, 136 Cal. Rptr. 581 n.6, 582.

48. Id. at 31-34, 560 P.2d at 8-10, 136 Cal. Rptr. at 579-81. The court also mentioned the successor corporation's reliance on its predecessor's goodwill. Why this should be a relevant factor in the absence of an estoppel argument is not clear. See Roe, Successor Liability, supra note 4, at 1566 , 1574 n.37.

49. 19 Cal. 3d at 33, 560 P.2d at 10, 136 Cal. Rptr. at 581 .

50. An interesting critique is the demonstration of economists that in a perfect market, manufacturers and suppliers have an incentive to provide warranty protection as a contractual term if consumers are willing to pay for it, even if the supplier has monopoly power. See generally Kennedy, Distributive and Paternalist Motives in Contract and Tort Law, with Special Reference to Compulsory Terms and Unequal Bargaining Power, 41 MD. L. REv. 563 (1982) (implied unwaivable warranties have a paternalist rather than an efficiency motive); Schwartz \& Wilde, Imperfect Information in Markets for Contract Terms: The Examples of Warranties and Security Interests, 69 VA. L. REV. 1387 (1983) (monopolists will supply contract terms that consumers prefer).

51. For a good discussion of the buyer's discount in the context of expected tort liability, see Note, The Inapplicability of Traditional Tort Analysis to Environmental Risks: The Example of Toxic Waste Pollution Victim Compensation, 35 Stan. L. REv. 575, 600-04 (1983) [hereinafter Note, Victim Compensation].

52. Roe, Successor Liability, supra note 4 , at $1566,1567$. 
servitude. Any creditor who could have asserted a claim in the liquidation of the seller may not sue the buyer. ${ }^{53}$

Second, other courts have picked up on the California Supreme Court's remark that it was "fair" that the buyer inherit personal liability because the buyer had purchased the trade name and appeared to the public to be the same corporation. They have tried to contain the products-liability servitude by requiring that the buyer have used the seller's goodwill. ${ }^{54}$ Connected with this limitation is the idea that the servitude encumbers the whole factory but does not encumber individual parts of the whole. ${ }^{55}$ Consequently, if a debtor sells a punch press out of his factory, the punch press does not carry the curse of servitude liability with it. This is similar to equitable servitudes on land, which do not attach to lumber and crops that were once connected with the burdened land. ${ }^{56}$

Third, courts have limited the products-liability servitude to cases where the seller ceases to exist after the sale. ${ }^{57}$ While this limitation prevents many servitudes from encumbering factories, it is of no assistance to a bankruptcy trustee who would like to sell the assets to raise cash for the existing creditors of the debtor.

53. 19 Cal. $3 \mathrm{~d}$ at $33 \mathrm{n} .6,560$ P.2d at $10 \mathrm{n} .6,136$. Cal. Rptr. at 581 n.6. For an application of this rule, see In re All American of Ashburn, Inc., 56 Bankr. 186, 189 (Bankr. N.D. Ga. 1986).

54. Bullington v. Union Tool Corp., 254 Ga. 283, 328 S.E.2d 726 (1985) (factory disencumbered because it was not used by purchaser to make table saws); Turner v. Bituminous Casualty Co., 397 Mich. 406, 426, 244 N.W.2d 873, 882 (1976) ("Continuity is the purpose, continuity is the watchword, continuity is the fact."). Jerry Phillips cites estoppel as the justification for this limitation. Phillips, Product Line Continuity and Successor Corporation Liability, 58 N.Y.U. L. REv. 906, 920 (1983) [hereinafter Phillips, Product Line]. Estoppel does not really work, however, in that it matters not at all what the future tort victim thought the facts were.

Jerry Phillips is not to be confused with David Phillips, who points out that the fairness claim-he who enjoys the predecessor's goodwill should pay the predecessor's tort debts-does not work either. Once the injury occurs and is publicized, the goodwill is destroyed, whether or not the successor corporation pays compensation. Phillips, Products Liability of Successor Corporations: A Corporate and Commercial Law Perspective, 11 Hofstra L. Rev. 249, 254-55 (1982) [hereinafter Phillips, Commercial Law Perspective].

55. For a discussion of potential problems with this limitation, see Roe, Successor Liability, supra note 4 , at 1590 .

56. Interestingly, in his article speculating on whether servitudes could encumber chattels, Zechariah Chaffee examined a similar situation, proposing that a servitude would survive only so long as the business enterprise (of which the chattel was a part) did. Chaffee, The Music Goes Round and Round: Equitable Servitudes and Chattels, 69 HARv. L. REv. 1250, 1257 (1956).

57. Kline v. Johns-Manville, 745 F.2d 1217, 1220 (9th Cir. 1984); Schumacher v. Richards Shear Co., 59 N.Y.2d 239, 245, 451 N.E.2d 195, 198, 464 N.Y.S.2d 437, 440 (1983). David Phillips defends this rule, arguing (plausibly) that when the buyer knows the seller will dissolve, the buyer is the leastcost avoider of the future tort claimants' insolvency risk and, therefore, should be liable. Phillips, Commercial Law Perspective, supra note 54, at 267-70. He argues (somewhat less plausibly) that this is not true when the buyer thinks the seller will continue to exist after the sale of assets. Id. at 271 . He does not develop his reasons for so believing, other than to note that the seller is "not responsible" when he does not know the buyer will liquidate. The least-cost avoider rationale, however, probably supports successor liability even when the predecessor hopes to survive. Compared to future users of defective products, the buying company probably has more knowledge of the selling company than consumers and is, therefore, better able to protect itself. But this explanation is merely a guess. I am aware of no data on comparative advantage in assessing the insolvency risk of the seller. Jerry Phillips, on the other hand, sees no justification for the requirement and would prefer a joint-liability rule. Phillips, Product Line, supra note 54, at 914-15. 
Finally, the Court of Appeals for the Ninth Circuit has ruled, apparently as a matter of California state law, that the products-liability servitude does not survive a bankruptcy sale where the buyer was uninvolved in the initial decision of the seller to file for bankruptcy. ${ }^{58}$ The court does not purport to formulate a federal rule of foreclosure (as will be proposed in this article), nor does its rule apply to each and every bankruptcy sale. ${ }^{59}$ Rather, the court draws upon the fact that in the Alad case, the buyer specifically contracted for the seller to dissolve.60 From this fact, the court deduced that the Alad doctrine must be limited to cases where the buyer is somehow morally responsible for the disappearance of the seller. Thus, where the buyer had no involvement in the seller's decision to file for bankruptcy, bankruptcy itself terminates the products-liability servitude. ${ }^{61}$

Although one might agree that the result of this last-mentioned limitation is desirable, the reasoning supporting such a limitation is weak for three reasons. First, under principles of federalism, the Ninth Circuit cannot rest its rule directly on good policy or common sense, but can only predict what California state courts may rule. A federal rule overriding state law would provide a stronger foundation for terminating the products-liability servitude in bankruptcy.

Second, the stated rationale for the rule was that the buyer in Alad contracted for the dissolution of the seller, while buyers in bankruptcy sales make no such contracts. It is not so clear, however, that buyers will always contract for their sellers to dissolve. In the case of many close corporations, the principals may so obviously wish to retire that no such undertaking is exacted. Perhaps the principals may have died and their estates are the sellers. Alternatively, the seller could simply substitute the personal covenants of the shareholders not to compete in lieu of the corporation's promise to dissolve. In these and similar cases, where the buyer has no need to impose anticompetitive restrictions on the seller, the buyer can avoid products-liability servitude liability simply by failing to mention the seller's dissolution in the sales contract. This possibility makes the Ninth Circuit's "guess" about California state law rather poor policy.

Finally, many buyers at bankruptcy sales are quite aware that they will benefit if the seller dissolves after the sale. In many cases, sellers will unilaterally file for bankruptcy simply to take advantage of the Ninth Circuit rule. Buyers who benefit from such strategic behavior by their sellers do not

58. Nelson v. Tiffany Industries, Inc., 778 F.2d 533 (9th Cir. 1985); see Ayer, How to Think About Bankruptcy Ethics, 60 AM. BANKR L.J. 355, 376 (1986).

59. Since the tort victims alleged that the buyer did advise the seller to file for bankruptcy before selling the assets, the court remanded the case to determine the extent of the seller's responsibility for the bankruptcy. Nelson, 778 F.2d at 617-38.

60. Id. at 536.

61. The Court of Appeals for the Fifth Circuit failed to find any such doctrine present in California law. See Mooney Aircraft v. Foster (In re Mooney Aircraft, Inc.), 730 F.2d 367, 371-72 (5th Cir. 1984). The Nelson court dismisses this precedent with the time-honored slogan of "dictum." 778 F.2d at 537 n.7. 
seem morally different from buyers more actively involved in the bankruptcy decision.

Due to these flaws in the Ninth Circuit's analysis, I will urge, as a separate bankruptcy doctrine, the creation of a foreclosure rule that would vindicate equality between present and future tort creditors. The scope of this rule will be discussed later in the article. ${ }^{62}$

\section{The Toxic-Waste Servitude}

A major issue that has recently surfaced is the allocation of liability for the cleanup of and the damages caused by toxic wastes. ${ }^{63}$ The law in this area has become monstrously complex. Overlaying the state law of nuisance is a plethora of state and federal statutes establishing liability that is uncertain in scope.

1. The Liability of Successors for Torts Caused by the Predecessor-in-Interest. The principles of Ray $v$. Alad Corp. certainly suggest that if a factory has emitted harmful pollutants, any buyer of the factory who has purchased from a seller that dissolves may well be liable to those plaintiffs whose claims were not mature at the time of the asset sale. Courts, however, have not yet extended Alad to include toxic-waste torts. ${ }^{64}$ Indeed, only one court has made this move to date.

62. David Phillips also favors an expanded foreclosure rule whereby buyers in bankruptcy sales should never be liable. Phillips, Commercial Law Perspective, supra note 54, at 271-72. He goes farther than the Nelson court, see supra note 61 , which would have preserved the servitude when buyers collude in their sellers' bankruptcies. His grounds for proposing such an expanded limitation is that (1) accurate calculations of future tort liability are more difficult in liquidations than in other contexts; and (2) successor liability would harm the creditors of the predecessors, a phenomenon that is explored in this article.

The first ground is not well justified, in my opinion. Many bankruptcy liquidations involve detailed bargaining, and there is no reason why actuarial risk should be harder to calculate when the seller is insolvent than when he is solvent. Indeed, with all the information about past tort creditors generated in a bankruptcy, perhaps risk assessment is even easier to calculate in rather than out of bankruptcy. See Southern R.R. v. Johnson Bronze Co., 758 F.2d 137, 142-43 (3d Cir. 1985) (buyer of bankrupt's factory held to be sophisticated and not defrauded by debtor-in-possession). Another phenomenon that I have witnessed is that when bankrupt companies sell their factories, the employees will tend to transfer their allegiance from the seller (who is abandoning them) to the buyer (who, they hope, will continue to employ them). These employees will be the single best source of information about a factory. I know of one large transaction where the employees were extremely anxious to disclose the secrets of the factory before the sale in order to ingratiate themselves with the buyer. When the seller is liquidating, this phenomenon is probably even more prevalent than in nonbankruptcy sales, where the sale might fall through and the seller might continue to run the factory.

Professor Phillips's second ground-intertemporal priority-provides a much stronger rationale and will essentially be the basis of my own suggestions for successor liability in bankruptcy.

63. See generally Staff of \& $301(\mathrm{E})$ Study Group, 97th Cong. 2d Sess., Injuries and Damages from Hazardous Wastes-Analysis and Improvement of Legal Remedies, Part I (Comm. Print Sept. 1982) [hereinafter 301 (E) STUDY].

64. Id. at 131-32. For example, Minnesota's comprehensive legislation carefully excludes the possibility of liability without culpability of some sort. Comment, Changes in the Ownership of Hazardous Waste Disposal Sites: Original and Successor Liability, 67 MARQ. L. REv. 691, 726-27 (1984) [hereinafter Marquette Comment]. One possible justification is that products liability, to some degree, arises out of an unwaivable warranty made in connection with the sale of goods, whereas toxic torts involve no such sale. Applying Alad to toxic torts, then (the argument goes), would be the same as applying $A$ lad , 
In Department of Transportation v. PSC Resources, Inc., ${ }^{65}$ a factory owned by Diamond Head had been dumping pollutants into a nearby lake since 1946. ${ }^{66}$ Diamond Head did not own the lake, which was located on property acquired by the New Jersey Department of Transportation in 1968.67 In 1973, PSC bought all of the Diamond Head stock, and soon thereafter, Diamond Head sold its assets, including the factory, to PSC for $\$ 100$ and then dissolved.68 PSC continued to operate the factory and pollute neighboring lands and waters through 1976.69 In 1977, the Department of Transportation was compelled to clean up its property at a cost of nearly $\$ 5$ million..$^{70}$ Although the court did not say so, the cleanup must have included oil spilled not only by PSC, but also by its predecessor, Diamond Head. PSC, however, was held liable for the entire cleanup cost. Although PSC's purchase of the factory for a nominal sum suggested fraudulent conveyance law or "piercing the corporate veil" as possible rationales for PSC's liability, the court instead chose to base its holding quite broadly on the rule that buyers of polluting factories are personally liable for the torts of their predecessors. ${ }^{71}$

\section{The Liability of Successors for Cleaning Up Toxic Wastes Left by the Predecessor-} in-Interest. A somewhat different question is whether the buyer is obligated to clean up toxic wastes left by the predecessor that are still present after the buyer has taken possession of property. Recent federal legislation governs this issue. The Comprehensive Environmental Response, Compensation, and Liability Act (CERCLA) ${ }^{72}$ establishes an emergency superfund financed in

to all torts, even those unrelated to the sale of goods. But tort victims who are injured unexpectedly would seem to have as much claim to the products-liability servitude as buyers of products. In fact, throughout products-liability law, the distinction between buyers and innocent bystanders has been blurred. See Elmore v. American Motors Corp., 70 Cal. 2d 578, 451 P.2d 84, 75 Cal. Rptr. 652 (1969); Gilberson v. Ford Motor Co., 504 S.W.2d 8 (Mo. 1974); Codling v. Paglia, 32 N.Y.2d 390, 298 N.E.2d 622, 345 N.Y.S.2d 461 (1973). Whatever rationale supports Alad, then, should also obtain in favor of nonbuyer victims of toxic-waste byproducts.

65. 175 N.J. Super. 447, 419 A.2d 1151 (Law Div. 1980); see Note, Successor Corporate Liability for Improper Disposal of Hazardous Waste, 7 W. NEW ENG. L. Rev. 909 (1985).

66. 175 N.J. Super. at 450,419 A.2d at 1152.

67. Id. at $450-51,419$ A.2d at $1152-53$.

68. Id. at $451,419 \mathrm{~A} .2 \mathrm{~d}$ at 1153 .

69. Id.

70. Id.

71. It is important to recognize that PSC considerably extended Alad in one respect. In Alad, only those with unmatured tort claims could get the benefit of the servitude, see supra text accompanying note 53; but in PSC, the Department of Transportation seemed to have a fully matured tort claim against the predecessor company at the time of the sale, as far as I can tell. Since the court did not focus on the timing aspect, however, it is possible to argue that the apparent extension of the Alad doctrine was unintentional.

On the basis of PSC, the EPA is apparently ready to argue that where it cleans up before sale to a buyer who then takes the factory free of toxic wastes, that buyer inherits the liability to reimburse the EPA for its cleanup costs. See Price, Liability of Corporate Shareholders and Successor Corporations for Abandoned Sites Under the Comprehensive Environmental Response, Compensation, and Liability Act, at 15 (undated internal EPA memorandum circa June 1984) [hereinafter EPA Memorandum]. Such a claim would be fully matured at the time of sale, however, and, therefore, arguably unentitled to the benefits of a servitude, at least if Alad is followed faithfully.

72. 42 U.S.C. $\$ \$ 9601-9657$ (1982). 
part by taxes on the petrochemical industry. ${ }^{73}$ Federal or state governments are allowed to draw from this superfund to subvent the cleanup of hazardous wastes. Reimbursement of these costs may then be sought from the owners of the toxic-waste "facilities." 74 In addition to this mechanism, the federal government may also obtain an injunction requiring landowners to abate health hazards posed by toxic wastes. ${ }^{75}$

One respect in which CERCLA is ambiguous is in describing the defenses available to landowners threatened with liability for reimbursement of cleanup costs. CERCLA section 9607 (b)(3) provides a defense to those who can prove that the environmental threat resulted from

\begin{abstract}
an act or omission of a third party other than an employee or agent of the defendant, or [other than (2)] one whose act or omission occurs in connection with a contractual relationship, existing directly or indirectly, with the defendant ... if the defendant establishes ... that (a) he exercised due care with respect to the hazardous substance ... and (b) he took precautions against foreseeable acts or omissions of any such third party and the consequences that could foreseeably result from such acts or omissions. ${ }^{76}$
\end{abstract}

As applied to buyers of land, this provision is distressingly vague. For instance, in the highly publicized Love Canal incident, the Hooker Chemical Co. had been storing dioxin and other noxious chemicals in an uncompleted canal. In 1954, after burying these toxic wastes but fully disclosing their existence, Hooker sold the land to a school district that built an elementary school on the site. ${ }^{77}$ If CERCLA had been in effect then, would the school

73. 26 U.S.C., ch. 38 (1982); 42 U.S.C. $\$ 9631$ (1982).

74. 42 U.S.C. $\$ 9607(a)(1)$ (1982). Section 9601 (9) defines a facility to be

(A) any building, structure, installation, equipment, pipe or pipeline ... well, pit, pond, lagoon, impoundment, ditch, landfill, storage container, motor vehicle, rolling stock, or aircraft, or (B) any site or area where a hazardous substance has been deposited, stored, disposed of, or placed, or otherwise come to be located ....

See generally, Developments in the Law-Toxic Waste Litigation, 99 Harv. L. Rev. 1459, 1515 (1986) [hereinafter Developments].

The owner of a facility does not include lenders with liens on the facility, unless such a lien is coupled with management of the facility. 42 U.S.C. $\$ 9601$ (20)(A) (1982). This exclusion prevents secured lenders (without management roles) from being held personally liable for toxic-waste cleanup. See Cohen, Hazardous Waste: $A$ Threat to the Lender's Environment, 19 U.C.C.L.J. 99, 110-15 (1986); but see Burcat, Environmental Liability of Creditors: Open Season on Banks, Creditors, and Other Deep Pockets, 103 Banking L.J. 509 (1986) (describing cases in which secured lenders who bid in their liens and took title at foreclosure sales were held liable for toxic-waste cleanup).

75. An unresolved controversy under CERCLA is whether the government must exhaust its legal remedies before seeking an injunction. One district court thinks so, characterizing superfund cleanup plus reimbursement as a legal remedy; but its holding is limited to offsite generators of toxic wastes. United States v. Wade, 546 F. Supp. 785, 792-94 (E.D. Pa. 1982), appeal dismissed, 713 F.2d 49 (3d Cir. 1983). The Court of Appeals for the Third Circuit, however, has stated a different view in dictum. United States v. Price, 688 F.2d 204, 212-13 (3d Cir. 1982). For some persuasive arguments in favor of granting injunctive relief without first requiring government cleanup, see Note, Abating an Imminent Hazard: Injunctive Relief under the Comprehensive Environmental Response, Compensation and Liability Act of 1980, 32 Buffalo L. Rev. 787 (1983) [hereinafter Buffalo Note].

76. 42 U.S.C. \& 9607 (b)(3) (1982).

77. Trilling, Painstaking Negotiation Leads to Landmark Court Order Approving Settlement Agreement in Hyde Park Hazardous Waste Cleanup Litigation, 12 Envtl. L. Rep. (Envtl. L. Inst.) 15,013 (1982); Note, Inactive or Abandoned Hazardous Waste Disposal Sites: Coping with a Costly Past, 53 S. CAL. L. REv. 1709, $1713 \&$ n.30 (1980) [hereinafter $S$. Cal. Note]. The Love Canal incident helped assure the passage of CERCLA through Congress. Buffalo Note, supra note 75, at 792-93. 
district, as owner of a "facility," have had a defense against reimbursement liability? Hooker is a third person, clearly enough, but did the disclosure render the environmental risk one that occurred "in connection with a contractual relationship" between Hooker and the school district? If the answer is no, the school district would presumably have had a defense. But if the answer is yes (which seems more appropriate), the school district would have had no defense if cleanup was foreseeably necessary. ${ }^{78}$

Even if subsequent landowners have a defense against reimbursement liability, they may still be liable under CERCLA's injunctive provision, section 9606(a), to which such a defense seems not to apply. ${ }^{79}$ If so, this may supply the government with an unhealthy incentive to forego cleanup efforts and to proceed instead by injunction, thereby circumventing the landowners' possible defenses against reimbursement actions. It would seem sensible, therefore, to construe the relevant limitations in the reimbursement provision to apply to the injunction provision as well in order to eliminate such an incentive. ${ }^{80}$

Just prior to enactment of CERCLA, Congress passed another environmental statute, the Resource Conservation and Recovery Act (RCRA). ${ }^{81}$ Unlike CERCLA, RCRA does not provide a superfund for the cleanup of hazardous wastes. Relief granted under RCRA is limited solely to injunctive relief, which is available on slightly different grounds than injunctive relief granted under CERCL.A. RCRA section 6973(a) requires

[U]pon receipt of evidence that the handling [or] storage . . of any . . hazardous waste may present an imminent and substantial endangerment to health or the environment, the Administrator may bring suit ... to immediately restrain any person contributing to such handling [or] storage ... to take such ... action as may be necessary. ${ }^{82}$

Again, it is unclear whether passive buyers of land can be held liable under RCRA on the theory that landowners who stand by and do nothing are "contributing to" the health hazard. ${ }^{83}$ No defenses to liability are expressly mentioned in RCRA.

78. New York v. Shore Realty Corp., 759 F.2d 1032, 1048-49 (2d Cir. 1985); Note, Hazardous Liability for Successor Owners of Toxic Waste Sites: New York v. Shore Realty Corp., 35 DEPAUL L. REV. 521,534 (1986) [hereinafter DePaul Note].

79. Of course, if one agrees with United States v. Wade, 546 F. Supp. 785 (E.D. Pa. 1982), appeal dismissed, 713 F.2d 49 (3d Cir. 1983), that the government must clean up and seek reimbursement first, the defense clearly becomes available in many more cases.

Only the federal government has standing to obtain an injunction under CERCLA. New York v. Shore Realty Corp., 759 F.2d 1032, 1049 (2d Cir. 1985).

80. Giblin \& Kelly, Judicial Development of Standards of Liability in Government Enforcement Actions Under the Comprehensive Environmental Response, Compensation and Liability Act, 33 CLEV. ST. L. REV. 1, 2021 (1984-85).

If the government obtains an injunction, it is entitled to treble damages for any governmental losses sustained "as a result of such failure to take proper action." 42 U.S.C. $\$ 9607(\mathrm{c})(3)$ (1982). This possibility could further encourage the government to delay cleanup, assuming that the government is a sufficiently cynical profit-maximizer.

81. 42 U.S.C. $8 \& 6901-6987$ (1982).

82. Id. \& $6973(\mathrm{a})$.

83. Giblin \& Kelly, supra note 80, at 25. Soon after RCRA was enacted, the EPA stated that innocent buyers could be sued under section 6973. 43 Fed. Reg. 58,984 (1978) (42 U.S.C. \& 6973 
As for the state law on the prospective cleanup of toxic wastes, one author has observed that state law generally provides a bona fide purchaser defense. ${ }^{84}$ If, however, the buyer of land has knowledge of the potential threat, state courts have imposed liability for cleanup. And when nuisance is the basis of liability, although the buyer may have an initial bona fide purchaser defense, it dissipates over time. If cleanup does not occur promptly, even a bona fide purchaser may be required to abate a nuisance. ${ }^{85}$

Although the matter is not absolutely certain, it appears that a buyer with knowledge of the toxic wastes at the time of his purchase will have either to decontaminate the land himself or to reimburse the government for doing so. ${ }^{86}$ The liability for toxic-wastes cleanup is usually only personal (that is, if the landowner does not comply voluntarily, the government must obtain injunctive relief or recover a money judgment against the landowner), although some states award themselves statutory liens to secure such obligations. ${ }^{87}$ But whether the obligation is a secured or an unsecured obligation, an array of foreclosure and priority problems will arise.

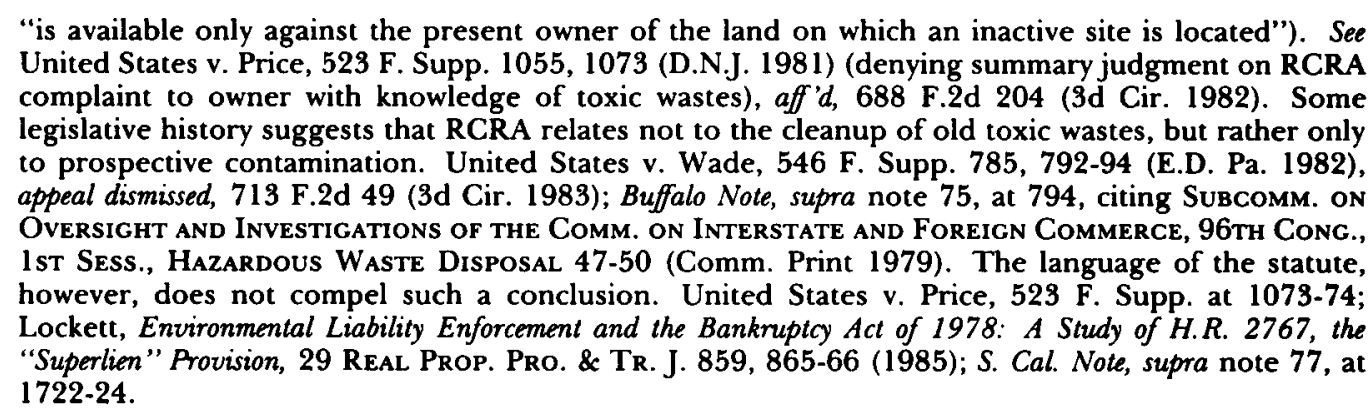

84. Mott, Liability for Cleanup of Inactive Hazardous Waste Disposal Sites, 14 Nat. Resources LaW. 379, 414-15 (1981); see also Marquette Comment, supra note 64, at 702-03, 707-09. For an example of a bona fide purchaser defense, see New Jersey Dep't of Envtl. Protection v. Exxon Corp., 151 N.J. Super. 464, 485, 376 A.2d 1339, 1349-50 (1977) (construing New Jersey oil-spill statute). States occasionally make landowners absolutely liable for abating nuisances. See Meadowlark Farms, Inc. v. Illinois Pollution Control Bd., 17 Ill. App. 3d 851, 861-62, 308 N.E.2d 829, 836-37 (1974); 901 (E) STUDY, supra note 63 , at 48 .

85. Clarke v. Boysen, 39 F.2d 800, 819 (10th Cir. 1939) ("The owner of land in possession whose predecessor in title or possession has created thereon a continuing nuisance is obligated to abate such nuisance after notice and knowledge thereof").

86. DePaul Note, supra note 78, at 539-40; Note, Hazardous Waste and the Innocent Purchaser, $38 \mathrm{U}$. FLA. L. REv. 253 (1986).

87. Cohen, supra note 74, at 115-23; Developments, supra note 74, at 1599-1601. Massachusetts and New Jersey, for example, supply themselves with a floating lien enjoying superpriority status on all the property of liable parties. See Mass. AnN. Laws ch. $21 \mathrm{E} \& 13$ (Law Co-op. Supp. 1986) (excluding residential real estate); N.J. Stat. ANN. \$ 58:10-23.11.f.f. (West Supp. 1986) ("Any expenditure made by the administrator [of the state department of environmental protection] pursuant to this act shall constitute a first lien ... paramount to all other claims and liens upon the revenues and all real and personal property of the discharger, whether or not the discharger is insolvent."); see Kessler v. Tarrats, 191 N.J. Super. 273, 466 A.2d 581 (N.J. Super. Ct. Ch. Div. 1983), aff'd, 194 N.J. Super. 136, 476 A.2d 326 (N.J. Super. Ct. App. Div. 1984) (upholding the retroactive application of the lien); Zarin, State Recovery of Hazardous Waste Cleanup Costs and Bankruptcy: The Constitutionality of Retroactive State Superpriority Lien Statutes, 90 Coм. L.J. 346 (1985) (arguing that retroactive application constitutes a fifth amendment taking); Note, The Constitutionality of Retroactive State Superliens for Toxic Waste Cleanup Reimbursement, 8 CARDOzo L. REv. 161 (1986) (arguing for constitutional retroactivity when the contaminated land is the collateral). The lien takes effect when various filings are made. N.J. StaT. ANN. \$ 58.10-23.11.f.f. (West Supp. 1986). In its controversial 


\section{The Foreclosure of Liens and the Unforecloseable Nature of Servitudes}

The whole purpose of a servitude is to guarantee that the new owner of property assumes his predecessor's personal liability, regardless of whether the new owner has consented to do so. From this premise, it follows that a lien foreclosure sale should never destroy a preexisting servitude. However, the immunity of servitudes to foreclosure creates inequalities between present and future claims. Perhaps such inequalities are less important at the state law level because creditor equality is less important as a state law norm than it is in bankruptcy. Nevertheless, since bankruptcy law defines the scope of the trustee's foreclosure powers in terms of state law, it will be useful to consider a series of anomalies that servitudes create when liens are foreclosed in bankruptcy.

First, consider an example involving a servitude creditor $(A)$, a mortgagee $(B)$, and an insolvent debtor $(D)$ who owns the land burdened by both encumbrances. $A$ has $\$ 15$ in accrued claims against $D$ and has obtained a judgment against $D$ personally. $A$ also has future claims against $D$ with a present value of $\$ 35$. Accordingly, anyone who might buy the land from $D$ would discount $\$ 35$ from the price she would otherwise be willing to pay because she would be assuming future servitude liabilities in that amount. Meanwhile, $B$ has a claim of $\$ 60$ against $D$ secured by a mortgage on $D$ 's land that was recorded before $A$ 's judgment and is currently in default. Finally, assume that $D$ 's land would be worth a maximum of $\$ 100$ if the servitude and mortgage could be removed.

Now, suppose $A$ were to enforce her judgment for $\$ 15$ against $D$ 's property, the same property that is already encumbered by $A$ 's servitude and $B$ 's mortgage. At the execution sale, $X$, who otherwise would be willing to pay $\$ 100$ for the land, would discount that price by $\$ 60$ for $B$ 's senior mortgage and $\$ 35$ for the future servitude liability to $A$, leaving a difference of $\$ 5$, the land's encumbered value to $X$. At this point, $A$ and $X$ would face a dilemma: If $X$ inherited $D$ 's accrued servitude liability $(\$ 15), X$ would have to pay at least $\$ 15$ to ensure that this past debt were extinguished; yet, he would be willing to pay only $\$ 5$. On the other hand, $A$ could sell the land only if she waived or subordinated her right to collect the entire $\$ 15$ judgment. Therefore, assume

\footnotetext{
Environmental Cleanup Responsibility Act, New Jersey has also empowered itself to force the seller to post a bond to assure the performance of the buyer. N.J. Stat. AnN. \& 13.1 K-9(b)(3) (West Supp. 1986); see In re Borne Chemical Co., 54 Bankr. 126, 132 (Bankr. D.N.J. 1984) (ruling that the Bankruptcy Code does not preempt this New Jersey statute). This provision allows the state to insist that the buyer's servitude obligation be guaranteed by a financially responsible third party.

Maine and New Jersey have also declared any property involved with illegal toxic-waste disposal to be subject to forfeiture. Me. Rev. Stat. Ann. tit. 38, \& 1306-C (Supp. 1984-85); N.J. Stat. AnN. $\$ \S 13.1 \mathrm{~K}-1$ to $13.1 \mathrm{~K}-5$ (West Supp. 1986). The transfer in Maine takes effect only when the state has obtained a judgment of forfeiture; if the debtor files for bankruptcy before (or soon after) the forfeiture has been decreed, the state is merely a general creditor without a property claim. In re Stevens, 53 Bankr. 783, 787 (Bankr. D. Me. 1985) (holding a judgment of forfeiture to be a voidable preference), rev'd on other grounds, 68 Bankr. 774 (D. Me. 1987).
} 
that $A$ and $X$ would agree that if $X$ were to bid up to $\$ 5$ for the land, neither $X$ nor his successors would be liable for the $\$ 10$ balance of $A$ 's past claims against $D$, but $X$ and his successors would continue to be liable on $A$ 's future claims. $X$ could now bid $\$ 5$ for the land; $A$ would receive only a partial recovery- $\$ 5$ out of $\$ 15$ - on her judgment against $D$; and $B$ would retain a mortgage for $\$ 60$ against $X$ 's land that would still be fully enforceable.

The results would be reversed, however, if $B$ rather than $A$ were the first to proceed against $D$. If $B$ were to enforce his mortgage against $D$ 's land, $X$, still valuing it at $\$ 100$, would discount that price by $\$ 15$ for the accrued servitude liability and $\$ 35$ for the future servitude liability to $A$ (both of which he would inherit), leaving a difference of $\$ 50$, the land's encumbered value to $X$. Hence, $B$ would recover $\$ 50$ on his $\$ 60$ secured claim (there would be a $\$ 10$ deficiency), in exchange for which his mortgage would be foreclosed; $A$ would not be prejudiced and might recover $\$ 15$ at will from $X$ and sue $X$ or any subsequent owner of the land on her future claims (now worth $\$ 35$ ) as they became due.

From this example, one can identify several anomalies:

\section{A. The Reverse Prisoner's Dilemma}

The first anomaly is readily apparent. The creditor who first enforces his claim will lose out to the creditor who sits on his rights. If $A$ proceeds first, $B$ will obtain a one hundred percent recovery; but if $B$ proceeds first, he will obtain less than a one hundred percent recovery. Likewise, $A$ will benefit if $B$ proceeds first but will suffer if she takes the initiative. ${ }^{88}$

This result would be avoided if $A$ and $D$ were to agree to a servitude mortgage, as illustrated in the Neponsit case, ${ }^{89}$ or if the court were to award $A$ an equitable lien as an implied term of the servitude. ${ }^{90}$ In either event, $A$ would gain the power to foreclose $B$ 's junior mortgage plus a priority over $B$

88. A similar phenomenon exists when liens have equal priority and cannot foreclose each other. This also creates a "reverse prisoner's dilemma"-each creditor has an incentive to do nothing in the hope that the other creditor will take the initiative. See Carlson, Simultaneous Attachment, supra note 10 , at $522-25$.

89. Neponsit Property Owners' Ass'n v. Emigrant Savings Bank, 278 N.Y. 248, 255, 15 N.E.2d 793, 795 (1938).

90. See supra note 26 . One court thought that covenants without equitable liens are manifestly useless and ineffectual. Mendrop v. Harrell, 233 Miss. 679, 103 So. 2d 418 (1958) (discussed supra note 26). This view is erroneous. It is possible to imagine servitudes that are unsecured obligations of the landowner. See text accompanying notes 88-99.

It may fairly be asked why a voluntary servitude creditor would ever agree to forego a consensual or equitable lien. Possibly, the debtor would refuse to acquiesce to a lien for a servitude for essentially the same reason that he would be reluctant to do so under any circumstances: It would raise the price to him of future credit. At least with the curiously circular priority created by an unsecured servitude obligation, a future mortgagee would have some prospect of seniority over the earlier unsecured servitude creditor and might be willing to reduce his price of credit accordingly. Also, since legal covenants do not run in the absence of such privity, perhaps the debtor might want to preserve the opportunity for misbehavior by destroying vertical privity and precluding personal liability. Finally, the debtor may have entered into antipledge covenants with other general creditors that he hopes are not violated by equitable servitudes. In any case, the dilemma described in the text is still a real one in the context of the involuntary products-liability servitude, where an equitable lien would be totally inappropriate (unless present creditors were also given a similar priority). 
in the cash proceeds of the mortgage sale. Meanwhile, $B$ could not foreclose $A$ 's rights by first enforcing his lien, for no matter who first initiated enforcement, $A$ would obtain a full recovery of $\$ 50$ and $B$ would obtain only a partial recovery of $\$ 50$.

\section{B. The Subordination of Creditors to Their Future Selves}

A second anomaly that emerges is that $A$ is junior to her future self. If $A$ enforces her claims against $D$ 's land before $B, X$ reduces his bid from $\$ 100$ to $\$ 40$ because $B$ 's $\$ 60$ mortgage is not foreclosed; but in addition, $X$ inherits $\$ 50$ in servitude liability to $A$. $A$, therefore, would have to agree to waive $\$ 10$ of her claims against $D$ if the execution sale is to go forward. Hence, $A$ recovers less than her $\$ 15$ judgment against $D$ largely because $A$, the present creditor, comes into conflict with $A$, the future creditor.

If $A$ 's servitude were a California-style products-liability servitude, the principle would work somewhat differently. Since the benefit of such a servitude inures only to those with unaccrued claims at the time of the sale, ${ }^{91}$ $X$ does not inherit servitude liability for any of the $\$ 15$ in accrued claims $A$ has against $D$. Hence, although $A$ still recovers less than her $\$ 15$ judgment against $D$, at least she is spared the indignity of being subordinated to her future self. Nevertheless, $A$ is subordinated to other future selves.

Toxic-waste liability presents yet another version of this same anomaly. The remedies available to the federal or state environmental authorities include injunctions enforceable by a court's contempt power and the restitution of amounts spent for the cleanup by the government. In either case, the landowner may wish to sell contaminated land to raise money for cleanup, or the government may wish to force a sale of the land to satisfy a money judgment or to foreclose a statutory lien. Since such a sale would subject any buyer to prospective cleanup liability, the buyer would reduce his offer in the amount of this expected cost. Accordingly, present cleanup or reimbursement for cleanup costs would be impeded by the fact that the job was not complete, and present recoveries would be sacrificed to future recoveries. Environmental authorities thus would be subordinated to their future selves.

\section{The Subordination of Present Secured Creditors to Future Unsecured Creditors}

A third anomaly is best presented in the context of the products-liability servitude, in which present secured creditors subsidize the recovery rights of future unsecured creditors. Assume a factory is worth $\$ 10$ million to its highest valuing user, but it is encumbered by a $\$ 5$ million mortgage. In addition, all potential buyers estimate the present value of future tort claims that would survive foreclosure of the mortgage to be $\$ 8$ million. Since these buyers know that in a foreclosure sale, they would take the factory free of the

91. See supra text accompanying note 53. 
mortgage lien but not free of the future tort claims, the highest valuing buyer would not bid more than $\$ 2$ million for the factory. The mortgagee, therefore, would suffer a deficit of $\$ 3$ million, recoverable only from the debtor, while the future tort claimants would be able to recover one hundred percent of their claims from the buyer of the factory as long as he remained solvent.

This third anomaly can be pressed further. If the debtor has no asset other than the factory, her general creditors, absent the servitude, could expect to share in the $\$ 5$ million of equity in the factory. But because the products-liability servitude preempts the debtor's equity, her present creditors lose out to the future creditors. Contrary to what might be expected when existing parties allocate scarce resources between themselves and future strangers, ${ }^{92}$ the future creditors in this case receive a full recovery that is subsidized by the present creditors. Furthermore, the ranks of the present general creditors are swollen by secured creditors who, owing to the servitude, cannot recovery fully from the collateral.

This anomaly might consequently supply an incentive to the mortgagee to sacrifice the going-concern value of the factory in favor of selling it for scrap, since the servitude does not appear to attach to the individual components of a business enterprise. ${ }^{93}$ Thus, if the mortgagee dismantles the factory and sells it piece-by-piece for $\$ 2.5$ million, he is better off than if he sells it intact. The future tort creditors are worse off, however, while society suffers a deadweight loss of $\$ 7.5$ million. ${ }^{94}$

\section{The Ability to Leverage-Out Future Creditors}

A fourth anomaly is that buyers of encumbered property have an incentive to block out future tort creditors with purchase money mortgages. If the lienenforcement-sale buyer purchases the property with the proceeds of an enabling mortgage loan, he acquires the property subject to a senior lien to which any future tort creditor's judicial lien will be subordinated. ${ }^{95} \mathrm{~A}$ further

92. The usual result is, of course, that present concerns are gratified at the expense of future concerns. Calabresi and Bobbit describe this phenomenon:

Consider the different attitude we all share toward the failure of Congress to pass truly effective safety legislation, as against the attitude we would have were it unwilling to appropriate funds

for the rescue of a trapped hostage. Lives may be discarded in both examples, but the choice is

less exposed in the first case and therefore less obstructive of some of the basic values involved. G. Calabresi \& P. Bobbitt, Tragic Choices 40 (1978). Besides the psychological phenomenon of denial described by Calabresi and Bobbitt, there is also the disposition to prefer one's own welfare today over the welfare of strangers tomorrow. See Marglin, The Social Rate of Discount and the Optimal Rate of Investment, 77 Q.J. EcoN. 95 (1963) (the calculus of collective savings versus consumption decisions is fundamentally different from the private calculus).

93. See supra text accompanying notes 54-55.

94. Jackson, supra note 3, at 93-94. Mark Roe dismisses this possibility as unlikely because shareholders would prevent management from making piecemeal sales. Roe, Successor Liability, supra note 4, at 1590. This assumes that any debtor equity would result only from the sale of a business as a going concern, but in the context of bankruptcy, debtor equity is probably nonexistent.

95. Mark Roe suggests that placing the assets in the hands of a subsidiary would also work, Roe, Successor Liability, supra note 4, at $1580 \mathrm{n} .55,1582 \mathrm{n.61}$; but this would essentially give the assets to the tort creditors entitled to sue the successor corporation. The successor can deprive these 
maneuver is necessary. Because the servitude liability is personal, care must be taken to ensure that the encumbered property is the buyer's only asset. To this end, the buyer might set up a subsidiary corporation for the sole purpose of buying and maintaining the asset. Thus, future tort creditors would be blocked out; the only property held by the buyer available to them would already be encumbered. Although few lenders would advance purchase money on a one hundred percent leveraged basis, the scheme could be supplemented with the personal guarantee of the shareholder. Because the guarantee would not be made to the tort creditors, the mortgagee could be provided with sufficient collateral and surety to justify extending the loan. ${ }^{96}$

This scheme could fail, however, if a court were to find that the mortgage constituted a fraud on creditors. Section 7 of the Uniform Fraudulent Conveyance Act provides: "Every conveyance made and every obligation incurred with actual intent . . . to hinder, delay or defraud either present or future creditors, is fraudulent as to both present and future creditors."97 But even if the buyer had engaged in a fraud within the meaning of this section, it does not necessarily follow that the mortgage would be avoided. Bona fide mortgagees have a good defense under section 9 of the Uniform Fraudulent Conveyance Act, which provides:

(1) Where a conveyance or obligation is fraudulent as to a creditor, such creditor ... may, as against any person except a purchaser for fair consideration without knowledge of the fraud at the time of the purchase, or one who has derived title immediately or mediately from such a purchaser, (a) [h] ave the convevance set aside ...98

While the bona fides of the mortgagee in such a scheme may be suspect, the allegation of bad faith is still a factual assertion that must be proven. Accordingly, it is fair to conclude that reliance on fraudulent conveyance provisions to frustrate circumvention of a state policy reveals a weakness in doctrine.

\section{E. The Retirement of Otherwise Useful Assets}

A final anomaly is that in cases of mass torts and toxic wastes where the present value of future claims exceeds the value of the encumbered property, no buyer would bid for the property at all.99 The only options, then, would be to retire the asset altogether or to sell it for scrap, if possible. Either option is wasteful.

creditors of even this value, however, if it can leverage the assets with a purchase money mortgage held by a friendly creditor.

96. Although courts have forced mortgagees in recent bankruptcy cases to abandon their collateral to the bankruptcy trustee and pursue the guarantor on a marshalling-of-assets theory, they have overlooked the fact that the guarantor is subrogated to the mortgagee's security interest in bankruptcy. Therefore, the general creditors do not really benefit from such rulings. See Note, Marshalling Assets in Bankruptcy: Recent Innovations in the Doctrine, 6 Cardozo L. Rev. 671, 684-85 (1985).

97. Uniform Fraudulent Conveyance Act $\S 7$, 7A U.L.A. 509 (1985).

98. Id. § 9, 7A U.L.A. 577 (1985).

99. See Kleinfeld, Allied Ends Pact with GAF: Asbestos Case Liability Cited, N.Y. Times, July 22, 1983, at D3, col. 1 . 


\section{SERVITUdes in BankRuptcy}

Theoretically, the value of a secured creditor's claim is unaffected by the debtor's bankruptcy. Either the collateral is surrendered to the secured party so that he may enforce his lien at state law, or the bankruptcy trustee gives the secured party adequate protection and retains the collateral for use or sale in the manner best calculated to benefit the general creditors. ${ }^{100}$ The trustee can maximize the sales price to the extent that she can sell the collateral unencumbered by outstanding property interests. Of course, because she inherits the debtor's interest, the trustee can at least sell an immunity from future legal interference by the debtor; and in addition, she can sell the collateral free and clear of the interests of third parties that are set forth in section 363(f) of the Bankruptcy Code, which is worth quoting:

(f) The trustee may sell property ... free and clear of any interest in such property of an entity other than the estate, only if-

(1) applicable nonbankruptcy law permits sale of such property free and clear of such interest;

(2) such entity consents;

(3) such interest is a lien and the price of which such property is to be sold is greater

than the aggregate value of all liens on such property;

(4) such interest is in bona fide dispute; or

(5) such entity could be compelled, in a legal or equitable proceeding, to accept a money satisfaction of such interest. ${ }^{101}$

Several provisions of section 363 (f) may affect liens. Subsection (1), for example, authorizes the sale of inventory unencumbered by article 9 security interests because the debtor is empowered to do so under section 9-307(1) of the Uniform Commercial Code. Subsection (3) mentions liens specifically, requiring that the trustee obtain a sale price high enough to pay lien creditors; if she cannot do so, the sale would not benefit the general creditors and the trustee would have to abandon the collateral. ${ }^{102}$ Subsection (5) also seems available to foreclose secured creditors if they could be compelled to join in a

100. 11 U.S.C. $\$ 363$ (1982 \& Supp. II 1985).

101. Id. §363(f).

102. "The trustee may sell free and clear if ... the sale price of the property is greater than the amount secured by the lien." H. REP. No. 595, 95th Cong., 1st Sess. 345 (1977). But see In re Beker Indus. Corp., 63 Bankr. 474 (Bankr. S.D.N.Y. 1986).

In Beker Industries, the court read section $363(f)(3)$ ("the price $\ldots$ is greater than the aggregate value of all liens") to mean that the trustee could administer the sale even when the price was below the face amounts of the secured claims. The court emphasized that "value" in section 363(f)(3) was not the same as face amount. 63 Bankr. at 476 . The problem with this view is that it almost eliminates any utility in section $363(\mathrm{f})(3)$. The aggregate value of the liens is, by definition, whatever price a well-run foreclosure sale brings in. Such a decision, if followed, would change the purpose of section $363(\mathrm{f})(3)$ from the principles mentioned in the text to simply a means of judicial review of the trustee's procedure of selling the collateral.

What the court had in mind, apparently, was that the trustee could have the secured parties' claims valued under section 506(a) and (if undercollateralized) split into its secured and unsecured portions. The reduced secured claim then becomes the "value" of the lien under section $363(f)(3)$. Any excess over this value belongs to the debtor's estate. There seems to be something wrong with the trustee underestimating the value of the collateral for purposes of section 506(a) and then profiting by such bad estimates under section $363(\mathrm{f})(3)$. Nevertheless, such a process is clearly what the Beker Industries case had in mind. 
foreclosure proceeding and accept cash in lieu of their liens. ${ }^{103}$ Whether any of these provisions permit the foreclosure of servitudes, however, is far less certain.

\section{A. Contractually Created Running Covenants in Bankruptcy}

The purpose of a lien is to generate cash proceeds from the sale of specific property with which to pay the lien creditor. This can never be done without foreclosing the enforcing creditor's lien. Hence, the above-detailed powers of the bankruptcy trustee make very, good sense. But whether bankruptcy trustees should be able to foreclose contractually created running covenants as well is another matter. The whole idea of running covenants on real estate is to prevent disencumbrance by sale. If section 363(f) of the Bankruptcy Code were read easily to authorize the destruction of servitudes, private landuse planning could be defeated by the bankruptcy of any participating landowner.

Nevertheless, section 363(f)(5) of the Bankruptcy Code could be used to foreclose such servitudes if servitude owners can be forced to accept cash in lieu of injunctive relief at state law. The trustee could then disencumber the land from servitudes, sell the land for its unencumbered value, demote the servitude creditors (if they are unsecured) to a low priority, ${ }^{104}$ and pay them a few cents on the dollar. Servitudes under this view would become simply executory contracts that could be rejected by a bankruptcy trustee. ${ }^{105}$

One principle that has long figured in equity jurisprudence is that courts will not grant an injunction when money damages will suffice. ${ }^{106}$ Generally, though, courts have not applied this principle to land-use cases because land

103. One case has limited the use of section $363(f)(5)$ to cases in which the lien creditors have received 100 cents on the dollar in lieu of foreclosure. In Richardson v. Pitt County (In re Stroud Wholesale, Inc.), 47 Bankr. 999 (Bankr. E.D.N.C. 1985), the trustee was seeking to sell collateral that was totally encumbered by various liens. Since the absence of debtor equity prevented use of section 363 (f)(3) to justify foreclosure, the trustee invoked section $363(f)(5)$, which has no such requirement. The court ruled, however, that at least in liquidations, section $363(f)(5)$ could be used to foreclose a junior lien only when the lien creditor had been fully compensated; otherwise, section 363(f)(5) would render section $363(f)(3)$ - with its debtor-equity requirement-superfluous. Because chapter 11 trustees supposedly need flexibility, this ruling was limited to chapter 7 liquidations. But see In re Beker Indus. Corp., 63 Bankr. 474, 478 (Bankr. S.D.N.Y. 1986) (holding that section 363(f)(5) cannot be used for liens even in chapter 11). For the Beker court's extremely prodebtor view on the meaning of section 363(f)(3), see supra note 102 .

104. This article will argue that nonforeclosure of toxic-waste servitudes and the administrativeexpense priority for toxic-waste cleanup are connected. See infra text accompanying notes 137-91. If this is true, foreclosure and ordinary priority should be connected as well. If the servitude creditor can be foreclosed but gets a high priority in bankruptcy, the general creditors of the debtor will be more or less indifferent as to whether or not servitudes are foreclosable since the buyer's discount (assuming no foreclosure and the buyer's assumption of servitude liability) would roughly equal the high priority claim that the servitude creditor would otherwise enjoy. That is to say, unless a bankruptcy court reduces the priority status of the servitude creditor, all the gain from foreclosure of the servitude would simply inure to the servitude creditor. If so, no important purpose would have been served by a foreclosure rule.

105. The trustee may not assume executory contracts without curing all existing breaches or providing adequate assurance of a cure. In addition, the trustee must provide adequate assurance that future performance will be satisfactory. 11 U.S.C. $\$ 365$ (b)(1) (1982 \& Supp. II 1985).

106. D. Dobes, Remedies 27-34 (1973). 
is supposedly unique. ${ }^{107}$ This justification may be sufficiently unconvincing ${ }^{108}$ to tempt some to suggest an "efficient breach" doctrine in land-use cases, under which breaching landowners could buy out servitudes by paying money damages. ${ }^{109}$

Whatever merits the efficient breach literature may or may not have as applied to running covenants, its effect in bankruptcy is potentially farreaching if, under section 363(f)(5) of the Bankruptcy Code, bankruptcy trustees could sell land free and clear of servitudes. Discussion of the efficient breach doctrine, premised on providing the plaintiff with a cash equivalence of his contract right (as valued by the market rather than by the plaintiff), usually assumes that the defendant is solvent and can pay. If, however, the efficient breach doctrine means that servitude owners "could be compelled, in a legal or equitable proceeding, to accept a money satisfaction of such interest" within the meaning of section $363(f)(5)$, and if servitude owners are merely general creditors in bankruptcy, then the trustee could foreclose servitudes and pay the owners a pittance. ${ }^{110}$ This amalgamation of efficient

107. J. Pomeroy, A Treatise on the Specific Performance of Contracts $\$ 10$ ( $3 \mathrm{~d}$ ed. 1926); see Rick v. West, 34 Misc. 2d 1002, 1008, 228 N.Y.S.2d 195, 201 (N.Y. Sup. Ct. 1962) (asserting a per se rule against damages over the opposition of the servitude creditor).

108. At least one court has challenged the notion that good substitutes never exist for real estate claims. Centex Homes Corp. v. Boag, 128 N.J. Super. 385, 320 A.2d 194 (N.J. Super. Ct. Ch. Div. 1974) (refusing specific performance remedy to a vendor of a condominium).

109. The "efficient breach" theory states that damages are preferable to injunctions whenever the defendant's opportunity costs exceed damages for breach of opportunity. Forcing the defendant to perform under such circumstances produces a deadweight loss. Theorists of this persuasion confuse transfer of consumer surplus with deadweight loss, however, and run afoul of the Coase Theoremfor which they are thoroughly horsewhipped in Macneil, Efficient Breach of Contract: Circles in the Sky, 68 VA. L. REv. 947 (1982). The purpose here in mentioning the efficient breach theory (or other theories favoring mandatory damages in land-use cases) is that bankruptcy foreclosure rules could wreak havoc with it. Most of the efficient breach theorists assume that the defendant actually pays up or actually has opportunity costs-neither of which usually follows in bankruptcy.

110. Assuming that the trustee can cash out servitude owners (and thereby be enabled to sell the property free of servitudes), it is difficult to resolve whether the servitude owners should be treated as lien-holders (deserving 100 cents on the dollar) or if they should be treated merely as general creditors. It has already been suggested that creditors are indifferent to foreclosure if the claims of servitude owners are always accorded a high priority. See supra note 104. Obviously, creditors would prefer to see the claims of cashed-out servitude owners get a low priority. This, however, depends on whether servitude owners are more like secured creditors or general creditors. Of course, if state law provides an independent lien, servitude owners are secured creditors; but if state law does not, then it would be appropriate to see if the servitude survives the trustee's power as a hypothetical lien creditor. 11 U.S.C. \$541(a) (Supp. II 1985). Yet that, too, ends up being an indeterminate test owing to the "reverse prisoner's dilemma" described supra in the text accompanying notes 88-90. If the trustee has a lien and enforces it first, her recovery will be consistent with a junior status; but if she has a lien and does nothing, her lien will be senior to any that the servitude owners may get and try to enforce. Accordingly, it is quite impossible to figure out whether servitude owners are more like secured or unsecured creditors.

I suggest that we focus instead on foreclosure as a means of achieving creditor equality. This view obviously favors treating servitude owners as general creditors when intertemporal equality is the only norm to be considered-in which case, the servitude should be foreclosed and the claim should be accorded a low priority. This view favors treating servitude owners as secured creditors when other norms (e.g., private land-use planning or financing decontamination of land) are deemed more important than creditor equality, in which case the servitude should not be foreclosed and the claim be accorded a high priority. 
breach rhetoric and bankruptcy foreclosure powers shows that damages are by no means the equivalent of injunctions in land-use planning cases.

One would hope that state law would not force damages on servitude creditors. Instead (subject to such matters as laches), they should have the right to elect remedies, in which case section 363(f)(5) would not foreclose their interests in bankruptcy.

It would be a mistake, however, for courts to rule that contractually created running covenants are always necessary for the continued existence of land-use planning. When a state insists upon rigorously enforcing the "touch and concern" requirement, running covenants, by and large, will be connected to the necessities of private land-use planning. But if a court allows purely financial covenants to run, foreclosure might be appropriate.

In Steffan v. McMillan (In re Coordinated Financial Planning Corp.), ${ }^{111}$ some cotenants promised each other a right of first refusal if either wanted to sell the cotenancy. The trustee wished to reject this "executory" contract, thereby disencumbering the land and allowing the trustee to sell it free and clear. The nondebtor cotenants countered with the argument that the executory contract was actually a covenant running with the land, an argument they must have viewed as effective in defeating the trustee's power to reject executory contracts. The court decided that the covenant did touch and concern the land under California law 112 but thought that the running covenant was a rejectable executory contract anyway. ${ }^{113}$

If the Steffen case had genuinely involved land-use planning, the result would have been unfortunate. But the right of first refusal at issue there seems unrelated to land-use planning and more in the nature of financial planning. As such, the court did well to treat the running covenant as foreclosable.

111. 65 Bankr. 711 (BAP 9th Cir. 1986).

112. The court's reading of California law seems highly questionable. California has codified the "touch and concern" requirement in statutory law as follows:

Each such act relates to the use, repair, maintenance or improvement of, or payment of taxes and assessments on, such land or some part thereof, or if the land ... consists of undivided interests in the same parcel ...., the suspension of a right of partition or sale in lieu of partition for a period which is reasonable in relation to the purpose of the covenant. . .

Cal. Civ. Code $\$ 1468$ (West 1972). Note that the covenant in Steffen does not relate to suspension of partition sales, as the statute requires.

The court cites two cases, but neither of them establishes that rights of first refusal touch and concern the land. Richardson v. Callahan, 213 Cal. 683, 3 P.2d 929 (1931) (covenant to discharge adverse liens ran with the land); Laffan v. Naglee, 9 Cal. 662 (1858) (assignee of lease also took right of purchase; court mentions "running with the land," but the case also included an express assignment of the rights and liabilities in the lease).

113. The court apparently felt that, once the covenant had been rejected, it had been converted from a property interest into a monetary claim in bankruptcy. I take this use of executory contract language to be merely a restatement of the idea that covenants can be foreclosed because the owners of them can be forced to accept money in lieu of other relief.

It does not follow, by the way, that each and every running covenant is an executory contract. Many running covenants will surely qualify as "executed" contracts to which the assumptionrejection rules of section 365 do not apply. 


\section{B. Systems for Foreclosing the Products-Liability Servitude in Bankruptcy}

In spite of the intertemporal inequality created by unforecloseable servitudes, it is fair to conclude that state courts and legislators would not want most contractual servitudes to be foreclosed in bankruptcies because private land-use planning would then become dependent on the solvency of land owners. On the other hand, they might well approve of bankruptcy foreclosure of the products-liability servitude once it were pointed out to them that unforecloseability of such servitudes might produce a temporal inequality among creditors that could be corrected only in this way. ${ }^{114}$ If the servitude were foreclosed, the assets could be sold for a price equivalent to their unencumbered market value, and present and future creditors could then divide the cash proceeds proportionally. For example, an estimate of future tort liability could be made on the basis of available data; and a fund could be created into which the future creditors' ratable share of the cash proceeds would be paid. Such an adjustment would correct any accidental inequality of distribution between present and future creditors.

Furthermore, such a fund for future tort claims could be used to reduce the uncertainty of future products liability. Mark Roe has described how the variable annuity concept can be used to mitigate the difficulty of estimating mass tort liability while providing the debtor respite from pending unforecloseable creditor's claims. ${ }^{115}$ One could use the same principles to administer a "servitude foreclosure fund." Between generations of creditors, the possibility of adjusting annual payments exists, so that no future creditor would be overcompensated at the expense of some competing future creditors. ${ }^{116}$

114. Section 363(f)(5) of the Bankruptcy Code, which provides that trustees may foreclose thirdparty property interests whenever "such entity could be compelled, in a legal or equitable proceeding, to accept a money satisfaction of such interest," 11 U.S.C. 363(f)(5) (1982), is rather confusing as applied to the products-liability servitude. Could a perfectly healthy individual who does not own a ladder and has no clear idea whether he will ever use one be compelled by a state court to accept a few pennies as compensation for the possibility that he may be injured by a ladder produced by the liquidating company? Compare Jackson, supra note 3, at $96, n .65$ (yes), with Roe, Mass Tort, supra note 4, at 866 ("it seems silly to compensate each employee ... when nine out of ten will go unharmed and one will be harmed"). Although it is difficult to imagine state courts so ruling, some beneficial effects can be achieved by bankruptcy foreclosure. Therefore, I would urge that section $363(f)(5)$ be read to permit foreclosure of the products-liability servitude and the achievement of intertemporal equality between creditors.

115. Roe, Mass Tort, supra note 4. Roe criticizes bankruptcy plans if they involve lump-sum payments to future tort creditors. Id. at 865 . Instead, he suggests that any tort creditor-present or future-be given yearly payments. Id. at $871-74$. Such a strategy allows for later adjustments if initial estimates of firm value or amount of creditors' claims prove wrong. Such an annuity would work even better for servitude foreclosures, because long-term uncertainty about firm value (in a reorganization) would not exist. The amount to which present and future tort creditors are entitled would be limited to the amount a buyer actually paid for an encumbered asset.

In the celebrated Manville bankruptcy, the court set up such funds specifically for tort creditors. The trust fund included not merely the proceeds of encumbered factories but a negotiated cash amount, Manville's obligation to pay money and profits in the future, and 80 percent of Manville's common stock. In re Johns-Manville Corp., 68 Bankr. 618, 622-23 (Bankr. S.D.N.Y. 1986). The opinion does not describe the rights of individual tort claimants to the fund, however.

116. Thomas Jackson also seems to favor a foreclosure rule, but he relies on some questionable premises. He writes: 
Tort claims ... that have been reduced to judgment [and, presumably, that generate no judicial liens] are simply treated by nonbankruptcy law as unsecured claims. In addition, those that have manifested themselves but have not yet been established by a court order are also treated, for purposes of nonbankruptcy distribution, like ordinary unsecured claims. The doctrine of successor liability arises in this last context.

Jackson, supra note 3, at 94-95 (footnote omitted). Jackson has not read the Alad opinion carefully enough. According to the sixth footnote, the products-liability servitude does not benefit creditors with assertable but unliquidated tort claims. Only those who could not have sued the buyer before liquidation get servitude rights. Ray v. Alad Corp., 19 Cal. 3d 22, 33 n.6, 560 P.2d 3, 10 n.6, 136 Cal. Rptr. 574, 581 n.6 (1977); see In re All American of Ashburn, Inc., 56 Bankr. 186, 189 (Bankr. N.D. Ga. 1986) (tort creditor denied servitude rights on this basis).

Because Jackson mistakenly perceives that present, not future, creditors enjoy the productsliability servitude, he favors foreclosure of the servitude: "Since in a bankruptcy proceeding, holders of unproved tort claims will be given their share of the assets and there is little reason to worry about unfair or quick distributions[s] . . . there may be no reason to adhere to that successorship doctrine." Jackson, supra note 3, at 96 (footnote omitted).

Jackson also asserts a second reason for foreclosure, which although overstated, is more persuasive. He believes that, if it were convenient to canvass their opinion, future tort creditors (who are, ex hypothesi, quite healthy and not yet injured) would cheerfully swap their servitude rights against buyers of the assets for a ratable share of a bankruptcy distribution:

The reason for this is that the inability of unascertained tort claimants to waive the "protections" of successor liability may actually leave them worse off, if they are consequently omitted from being considered claimants in the bankruptcy process, as the creditors that control the disposition may push for piecemeal liquidation when the unascertained claimants will be left with nothing.

Id. at 96 (footnote omitted). The observation that inefficient piecemeal sales are possible when servitudes are unforeclosed in bankruptcy is a good point, but it is hard to sell a foreclosure rule on the ground that servitude creditors (uninjured and unlikely to foresee an injury) would always trade in their future rights for it. Servitude creditors would not want such a rule if the bankruptcy trustee would gain nothing from a piecemeal sale. This would occur when the difference between the liquidation value and going-concern value exceeded the value of the servitude, or

$$
\mathrm{S}<\mathrm{G}-\mathrm{L}
$$

where $S=$ the value a buyer would place on assuming the servitude liability, $G=$ going-concern value of the asset, and $\mathrm{L}=$ the value in a piecemeal sale.

Whether piecemeal sales do or do not benefit nonservitude creditors at the expense of the servitude creditors is almost impossible to say as a general matter. Jackson would need a firm grasp on the average amount of servitude liability and the average difference between going-concern and piecemeal value of American industry, two empirical facts conspicuously absent from Jackson's work.

In any case, if the idea is to give servitude creditors what they want, as Jackson assumes, surely they would much rather have an absolute rule against piecemeal sales in lieu of a foreclosure rule. But such a rule would create intertemporal inequality between creditors. In my view, servitude creditors have no good moral claim to priority over present creditors. Intertemporal equality is the best justification for a foreclosure rule.

A final criticism of Jackson's views is that he thoroughly undermines his own position by stating that a foreclosure rule

rests on nonbankruptcy policy. In effect, one is attempting to determine how nonbankruptcy law would treat the tort successorship doctrine after a sale of assets when all "existing" claimants were provided for (albeit, perhaps, because of insolvency, not in full). If one concluded that tort successorship doctrine were inapplicable in that context, then bankruptcy law simply mirrors that conclusion by not using it in bankruptcy.

Id. at 97. Of course, the products-liability servitude is applicable precisely in cases where existing creditors are provided for. It operates for the benefit of future creditors, who could not have been provided for under state law. Hence, if he adheres to the view that state law must decide the question, Jackson would have to conclude that the servitude should not be foreclosed in bankruptcy, even though wealth is transferred from present creditors to future creditors. But see Nelson v. Tiffany Indus., Inc., 778 F.2d 533, 538 (9th Cir. 1985) (federal court "guesses" that as a matter of California state law, bankruptcy sales foreclose servitudes in cases where the buyer is not involved in the seller's decision to file for bankruptcy). What is needed, therefore, is a federal foreclosure rule that would 
Unless future tort claimants who are not yet injured are "creditors" within the meaning of the Bankruptcy Code, however, there are severe statutory"17 and constitutional ${ }^{118}$ impediments to the establishment of such a foreclosure fund. At least some courts have assumed that persons exposed to asbestos are present contingent claimants because their exposure may lead to

obliterate the state-created products-liability servitude. The analysis is very much a bankruptcy question, quite contrary to Jackson's observation.

Douglas Baird also favors a foreclosure rule in an article in which he discovers (presumably through undisclosed empirical research) that creditors would like to repeal chapter 11, since they believe that bankruptcy judges are unreliable valuers of assets. Baird, The Uneasy Case for Corporate Reorganization, $15 \mathrm{~J}$. LEGAL STUD. 127 (1986). I must confess that I do not fully grasp his rationale for a foreclosure rule. See id. at 145-46. He seems to reason that buyers will bid less without a foreclosure rule, which is undeniably true. However, for someone who believes that rights conferred by state law should be preserved in bankruptcy, Baird, $A$ World Without Bankruptcy, Law \& ConTEMP. ProBs., Spring 1987, at 187-91 [hereinafter Baird, World Without Bankruptcy], this rationale alone hardly would seem to suffice. A better rationale rather would seem to be that the lower bids translate into a priority for future creditors. This violates the weak bankruptcy norm in favor of equality, which, in the absence of any competing policy, would favor foreclosure.

117. The Bankruptcy Code defines the word "claim" very broadly. See 11 U.S.C. $\$ 101(4)$ (1982) ("right to payment, whether or not such right is reduced to judgment, liquidated, unliquidated, fixed, contingent, matured, unmatured, disputed, undisputed, legal, equitable, secured, or unsecured ..."). The problem is that a "creditor" is defined in section $101(9)(A)$ as an "entity that has a claim against the detor that arose at the time of or before the order for relief concerning the debtor." At least some courts have read this statutory language to allow bankruptcy to affect the claims of future tort creditors. In re Amatex Corp., 755 F.2d 1034, 1042-44 (3d Cir. 1985) (allowing class representative for future tort creditors without deciding that future tort creditors have "claims"); In $r e$ UNR Indus., Inc., 725 F.2d 1111, 1119-20 (7th Cir. 1984) (dismissing appeal from 29 Bankr. 741 (N.D. Ill. 1983) and stating in dictum that the question was to remain open); In re UNR Indus., Inc., 46 Bankr. 671, 674 (Bankr. N.D. Ill. 1985) (on remand, disavowing the negative view of the district court, infra); In re Johns-Manville Corp., 36 Bankr. 743, 754-56 n.6 (Bankr. S.D.N.Y. 1984), appeal dismissed, 39 Bankr. 234 (S.D.N.Y. 1984); see also Jackson, supra note 3, at 82-83; Roe, Mass Tort, supra note 4, at 892-905; Developments, supra note 74, at 1589-92. Other courts, however, have found the statutory language to bar the inclusion of claims of future creditors. Schweitzer v. Consolidated Rail Corp., 758 F.2d 936, 939, 944 (3d Cir.) (interpreting $\$ 77$ of the Bankruptcy Act of 1898 as amended, formerly codified at 11 U.S.C. $\$ 205$, repealed 1978), cert. denied, 106 S. Ct. 183 (1985); Mooney Aircraft Corp. v. Foster (In re Mooney Aircraft, Inc.), 730 F.2d 367, 375 n.6 (5th Cir. 1984) (specifically rejecting the possibility of foreclosing a products-liability servitude, but noting that the definition under the new Bankruptcy Code is broader than under the Bankruptcy Act of 1898); In re UNR Indus., Inc., 29 Bankr. 74 1, 745 (N.D. Ill. 1983), appeal dismissed, 725 F.2d 1111 (7th Cir. 1984); Gladding Corp. v. Forrer (In re Gladding Corp.), 20 Bankr. 566, 568 (Bankr. D. Mass. 1982).

Sometimes these cases are presented in a posture that obscures the intertemporal inequality issues. In the Schweitzer case, for example, when asbestosis victims with illnesses manifested after a bankruptcy sued to recover damages for their injuries, the defendant companies, which were undergoing reorganization, responded that they had been discharged from these claims. Schweitzer at 939-41. The Court of Appeals for the Third Circuit held on statutory grounds that the unaccrued tort claims had not been discharged in the bankruptcy, presumably because the defendants seemed to be using a technical argument to withhold compensation from deserving plaintiffs. See id. at $\mathbf{9 4 4}$. However, if this holding were generally applied to prevent foreclosure of products-liability servitudes in bankruptcy, the strategic reaction of the business community probably would be to discount the price of the encumbered assets by the amount of future assumed liabilities. Thus, existing creditors would subsidize recoveries for future creditors (where the future tort claims were less than the value of the asset), or future creditors would recover nothing at all (as all potential buyers would have been discouraged since assumed liabilities exceeded the value of the asset). The Schweitzer opinion does equivocate slightly in a footnote, however, in which the court reserves judgment as to whether a reorganization could ever have an effect on future tort creditors. See id. at $944 \mathrm{n}$.l. However, since the court ruled that future tort creditors were not "creditors" under the Bankruptcy Act, see id. at 942-43, it is hard to see how a plan could have any effect on future tort claimants.

118. Schweitzer at 944; Mooney Aircraft at 375. 
products-liability claims. ${ }^{119}$ The arguments in favor of bringing such claimants into a bankruptcy plan are similar to the arguments for subjecting future tort claimants to a foreclosure rule. ${ }^{120}$

The Court of Appeals for the Fifth Circuit, in Mooney Aircraft Corp. v. Foster (In re Mooney Aircraft, Inc.), has refused to allow a bankruptcy court to foreclose a products-liability servitude on an airplane factory. ${ }^{121}$ In that case, a buyer of a factory at a bankruptcy sale had received a blanket assurance from the bankruptcy referee that the factory was free and clear of "claims, liabilities, liens. . . and security interests."122 Future products-liability servitude creditors had not been represented in the bankruptcy proceeding; indeed, the servitude had not yet been invented. ${ }^{123}$ Later, plaintiffs who had been injured by an airplane manufactured by the bankrupt succeeded in preventing the buyer from asserting a foreclosure defense to their tort suit. ${ }^{124}$

Fortunately, it is possible to identify some distinguishing features of the Mooney case. First, no guardian ad litem for future creditors had been appointed in the bankruptcy where foreclosure was attempted. If one had, perhaps the court's due process concerns would have been allayed. Second, the case was decided under the Bankruptcy Act of 1898, and the court noted some legislative history suggesting that the new Code definition of "claim" under the Bankruptcy Code was broader than it had been under the former Act. ${ }^{125}$ Coupled with a guardian ad litem, this broader definition of "claim" should supply the doctrinal basis to support a foreclosure rule.

One final thought should be added to round out the discussion of a foreclosure rule. It was noted earlier that under state law, a secured creditor seeking to enforce his lien through a sale would be junior to the owners of the products-liability servitude. ${ }^{126}$ If the servitude were foreclosed in bankruptcy in the name of intertemporal priority, the secured party's collateral would increase in value because buyers would bid a price reflecting its unencumbered value. Unless some preventive steps were taken, this increased value might go to the secured creditors. ${ }^{127}$ Clearly, this should not be allowed, since the trustee does not undertake the avoidance of property interests for the benefit of secured creditors. One doctrinal tool the trustee

119. See supra note 117.

120. It is argued that since bankruptcy generally accelerates claims due in the future, this rule should also apply to unmatured tort claims. See Jackson, supra note 3, at 82-83. In addition, it is argued that even if the injury has not yet occurred, if somebody owns a defective product at the time of bankruptcy or has already been exposed to an injury-causing substance, the present nature of the future claim justifies full acceleration of the remaining future aspects of the claim. See Roe, Mass Tort, supra note 4, at 896-97.

121. Mooney Aircraft at $\mathbf{3 7 5}$.

122. Id. at 369 .

123. See id. at 369-71. The sale of the productive assets occurred in 1969. Id. at 369-70. Ray $v$. Alad, which created the products-liability servitude, was decided in 1977. Ray v. Alad, 19 Cal. 3d 22, 560 P.2d 3, 136 Cal. Rptr. 574 (1977).

124. Mooney Aircraft at 374-75.

125. Id. at 375 n.6.

126. See supra text accompanying notes 89-92.

127. I am indebted to Elizabeth Warren for pointing out this concern. 
could use to ensure that this added value is retained by the general creditors would be to split the secured creditor's claim into its secured and its unsecured components pursuant to section 506(a) of the Bankruptcy Code. ${ }^{128}$ Once the secured claim were so limited, any increase in value stemming from a foreclosure rule would be free from the secured party's claim.

\section{Toxic Wastes in Bankruptcy}

Intertemporal equality between products-liability victims is a self-financing program because an asset exists that can be sold. But a toxic-waste problem in bankruptcy is less tractable because there is no painless source of funds to clean up the contamination.

One source of such funds has already been ruled out by the United States Supreme Court. In Ohio $v$. Kovacs, the state of Ohio obtained an injunction against a corporate polluter and its president, Kovacs, who then filed for bankruptcy. ${ }^{129}$ Ohio had failed to realize funds for cleanup from either the corporation or Kovacs, and so it attempted to reserve rights against his future wages, claiming that the injunction against Kovacs ordering the cleanup was nondischargeable in his bankruptcy. ${ }^{130}$ Because toxic-waste cleanup orders are not listed as a nondischargeable claim in section 523(a) of the Bankruptcy

128. 11 U.S.C. $\$ 506$ (a) (1982). The freeze-out of secured creditors is also possible in toxic-waste cleanup cases. But even if freeze-out is disallowed, the resulting appreciation of value should equal the trustee's cleanup expense, more or less. The trustee, therefore, should be able to charge the secured party with this expense on the theory that the cleanup constitutes "the reasonable, necessary costs and expenses of preserving [the collateral] to the extent of any benefit" to the secured party. $I d . \S 506$ (c). The ability of the trustee to charge the secured party with expenses incurred to enhance the value of collateral should prevent the notorious election of section 1111(b) from being a concern in chapter 11 cases. Where the contaminated land is to be sold, the election is only permitted to nonrecourse lenders. 11 U.S.C. $\$ 1111$ (b)(1)(B)(ii) (1982). If an undersecured lender makes the election, all appreciation in value goes to the electing lender.

Theodore Eisenberg suggests a radically different reading of section $1111(\mathrm{~b})$. In his view, the secured party does not merely capture appreciation value, but is guaranteed recovery of the face value of the secured claim. Eisenberg, The Undersecured Creditor in Reorganizations and the Nature of Security, 38 VAND. L. REv. 931, 937-40 (1985). For instance, suppose the nonrecourse lender has lent $\$ 1,000,000$, and the contaminated land is worth zero before cleanup and $\$ 100,000$ after cleanup. Under Eisenberg's reading, the electing lender is still entitled to receive $\$ 1,000,000$. This is not such an implausible reading, given the language of section 1111 (b)(2):

If such an election is made, then notwithstanding section 506(a) of this title, such claim is a secured claim to the extent that such claim is allowed.

11 U.S.C. $\$ 1111(\mathrm{~b})(2)$ (1982). Under Eisenberg's reading, section 506(c) expenses could not diminish the electing creditor's claim.

My own interpretation of section $1111(\mathrm{~b})$ is that the electing creditor may never receive more than the collateral is worth after appreciation. This reading is supported by section 1129(a)(7)(B), which states that a chapter 11 plan must give electing lenders "property of a value ... that is not less than the value of such holder's interest in the estate's interest in the property that secures such claims." 11 U.S.C. $\$ 1129$ (a)(7)(B) (1982). This language quite clearly connects the rights of the electing lender to the actual value of the collateral. It also holds open the possibility that when the trustee spends money to increase the value of the collateral, this can be charged to the electing lender's account.

I am first to admit that my reading is not free of problems, but space does not allow a full exposition of the astonishing complexities in section 1111 (b).

129. Ohio v. Kovacs, 105 S. Ct. 705 (1985); see generally Comment, The Future of the Environmental Enforcement Injunction After Ohio v. Kovacs, 13 B.C. ENvTL. AFF. L. Rev. 397 (1986).

130. $105 \mathrm{~S}$. Ct. at 706. 
Code, Ohio resorted to the rather implausible argument that the injunction was not a claim at all. ${ }^{131}$ Rebuff ensued at all levels of the federal court system, and Kovacs won his discharge.

Although the Kovacs holding does not bear directly on priority problems in bankruptcy, the opinion includes some rather detailed comments that suggest a lot of answers. These comments have been modified and supplemented by the United States Supreme Court in Midlantic National Bank v. New Jersey Department of Environmental Protection. ${ }^{132}$ Taken together, these opinions create three separate priority rules, applicable to different sets of facts. First, there is the $(0<[\mathrm{c}-\mathrm{f}]<[\mathrm{v}-\mathrm{m}])^{139}$ priority rule. ${ }^{134}$ Second, there is the $(\mathrm{e}>[\mathrm{c}-\mathrm{f}]$ $>[\mathrm{v}-\mathrm{m}])$ rule, to which the Midlantic National Bank case is directly relevant. ${ }^{135}$ Third, there is the $(\mathrm{e}<[\mathrm{v}-\mathrm{m}]<[\mathrm{c}-\mathrm{f}])$ situation, which a few courts since Midlantic have now considered. ${ }^{136}$ In each of these cases, priority of the government's claim and the forecloseability of the toxic-waste servitude are integrally connected. The connection is precisely this: So long as the trustee cannot promise a transferee of the contaminated land an immunity from toxic-waste liability (which is obviously the case), postbankruptcy cleanup expenses will have a high priority in bankruptcy. High priority of postbankruptcy cleanup expenses follows directly from the trustee's inability to foreclose a toxic-waste servitude on land owned by the bankrupt estate. In

131. Id. at 708-09. "While the state's position may strike bankruptcy lawyers as implausible, it has the direct support of thirty-two other states and the United States Department of Justice." Hennigan, Accommodating Regulatory Enforcement and Bankruptcy Protection, 59 Aм. BanKR. L.J. 1, 2 (1985).

132. 106 S. Ct. 755, reh'g denied, 106 S. Ct. 1482 (1986).

133. In this and the following expressions:

$c=$ the cost of decontaminating the land.

$f=$ the portion of decontamination costs chargeable to mortgagees under section $506(c)$ of the Bankruptcy Code, which provides:

The trustee may recover from property securing an allowed secured claim the reasonable, necessary costs and expenses of preserving, or disposing of, such property to the extent of any benefit to the holder of such claim.

11 U.S.C. $\$ 506$ (c) (1982). Assuming that the secured claim has not been valued under section 506(a) of the Bankruptcy Code yet or that the secured party is oversecured, $f=c$, where (c < $[m-p]) ; f=c-m-p$, where $(c<[m-p])$. If the secured party is undersecured and has been accorded precleanup value for the contaminated collateral, $f=0$. In such a case, $v-m-c$ is for the benefit of the general creditors.

$v=$ the value of the land after it is decontaminated.

$\mathrm{m}=$ the face amount of claims secured by the decontaminated land.

$\mathrm{e}=$ the amount of the bankrupt estate, minus whatever superpriorities have been promoted over the government's toxic-waste priority.

$p=$ the value of the contaminated land (prior to cleanup); $p \geq 0$.

134. When $[c-f]<[v-m]$, cleaning up the land is a paying proposition. Once the land is cleaned up, the bankruptcy trustee could sell it profitably. Of course, trustees or their buyers, if they are profit-maximizers, may prefer to export pollution costs to the public. But if trustees must internalize these costs pursuant to environmental law, they would still have no incentive to abandon the land, if that were possible, since $[v-m-c-f]$ represents a net gain to the estate.

135. When $(e>[c-f]>[v-m])$, the profit-maximizing trustee would prefer to abandon the land if he could; but if he cannot, he can, nevertheless, pay for decontamination, because the bankrupt estate (e) exceeds the cost of cleanup (c - f).

136. In the case of $(e<[v-m]<[c-f])$, the cost of cleanup exceeds the entire value of the bankrupt estate. Therefore, the trustee could not decontaminate fully the land even if required to do so. Abandonment is inevitable. 
contrast, a nonservitude liability to decontaminate the land of another would produce a mere general claim in bankruptcy.

\section{Cases in Which the Value of the Land (Once Decontaminated) Exceeds Cleanup} Cost: $(0<[c-f]<[v-m])$.

a. The Connection Between Servitude Liability and High Priority. Section 507(a)(1) of the Bankruptcy Code gives the top priority to the expenses of administering the bankrupt estate. This priority, like the top priority of sheriff's fees in execution sales, is based on the sobering truth that no one would administer estates or liquidate property unless her claim were accorded such elevated status; otherwise, goods or services supplied by the trustee would effectively be viewed as charitable contributions to prebankruptcy creditors. ${ }^{137}$ The standards defining administrative expenses that have evolved can be quite simply stated: Credit transactions occurring after bankruptcy that help preserve the estate are administrative expenses; credit transactions occurring before bankruptcy never are. ${ }^{138}$

Those who take the view that toxic-waste servitudes should not be foreclosed in bankruptcy will find themselves committed to the view that cleanup measures undertaken after bankruptcy are administrative expenses. Since environmental law apparently requires all landowners to clean up their land, bankruptcy, which transfers contaminated land from the debtor to the trustee, transfers landowner's liability to the trustee as well. ${ }^{139}$ If the trustee could not promise subcontractors cash or high-priority credit for cleaning up, she would be unable to fulfills her obligation to decontaminate. 140 Accordingly, her only viable alternative would be to sell the contaminated land to a buyer who, having inherited the obligation to clean up, ${ }^{141}$ would

137. See S. REP. No. 1395, 82d Cong., 2d Sess. 5 (1952) ("Unless provision is made for payment of the costs ... necessary to liquidate ... there is always a danger of a breakdown of administration.").

138. 11 U.S.C. $\$$ 503(b) (West Supp. 1985); 3 W. Collier, Bankruptcy $\uparrow 507.04$ (King ed. 1985).

139. The transfer from debtors to bankrupcy trustees is characterized as transfer by judicial lien attachment (in the case of real property or personal property) and by bona fide purchase (in case of all real property except fixtures). 11 U.S.C. \$ 544(a) (West Supp. 1985). Thus, at least as to personal property, the trustee is a secured creditor. CERCLA contains language excluding secured lenders from being termed "owners," but it also stipulates that the secured lender must not participate "in the management or operation of a . . facility." Those tempted to argue that the trustee is somehow an excepted secured lender cannot get around the fact that bankruptcy trustees are also very clearly "managers" of facilities. See generally Burcat, supra note 74, at 513-15.

140. Of course, one could impose personal liability on the trustee, forcing him to dip into his own assets to pay for toxic-waste cleanup. But this very quickly would dry up the pool of persons willing to serve as bankruptcy trustees. See In re Stevens, 53 Bankr. 783, 788 (Bankr. D. Me. 1985) ("The trustee's obligations in a chapter 7 case are necessarily reduced by the nature of his office into monetary obligations and ... are confined to what may be allowed as an administrative expense."), rev'd on other grounds, 68 Bankr. 774 (D. Me. 1987); see In re T.P. Long Chem., Inc., 45 Bankr. 278, 283 (Bankr. N.D. Ohio 1985) (trustee does not personally own contaminated land and hence is not personally liable for toxic-waste cleanup).

141. Admittedly, the government might step in and clean up immediately, even if its expenses were accorded a low priority; but the government would have the same incentive as the trustee to wait until the trustee sold the contaminated land to a buyer, who would then inherit liability for cleanup. For this reason, it is important that the government obtain the same high priority as the 
obviously discount the cost of cleanup from the price bid, thereby diminishing the bankrupt estate by approximately the same amount as would have been the case had the cost of cleanup been accorded administrative expense status.

These scenarios strongly suggest that general creditors would be indifferent to the priority accorded toxic-waste cleanup costs, unless the toxicwaste servitude were forecloseable. In fact, according a low priority to these costs would be counterproductive. It would encourage the trustee to leave the cleanup to the buyer, thereby prolonging and increasing the harm to the public. If the trustee or the government could have cleaned up the land for less than what buyers perceived the costs would be, the price of the land would have been excessively discounted (diminishing the bankrupt estate pro tanto) and the general creditors would have suffered a corresponding loss. Clearly, it would be preferable to allow the trustee or the government to choose between cleanup (with a high priority) or selling, whichever promised to be the more efficient. ${ }^{142}$

In effect, courts have already committed themselves to nonforeclosure of toxic-waste servitudes. In Midlantic, the Supreme Court ruled that the trustee could not abandon contaminated land without first complying with environmental law. ${ }^{143}$ If the trustee cannot personally escape this responsibility, it seems fair enough to conclude that the trustee cannot permit buyers of contaminated land to escape their responsibility either. Furthermore, in Penn Terra Ltd. v. Department of Environmental Resources, ${ }^{144}$ the Court of Appeals for the Third Circuit ruled that injunctions forcing cleanup are exempted from the automatic stay by sections $362(\mathrm{~b})(4)$ and (5) of the Bankruptcy Code. ${ }^{145}$ Nothing in section 363 of the Bankruptcy Code

trustee for postbankruptcy cleanup reimbursements. See In re Mowbray Engr. Co., 67 Bankr. 34, 36 (Bankr. M.D. Ala. 1986) (granting EPA administrative priority).

142. Dictum from Kovacs states that when the cost of cleanup is less than the value of the land (absent the toxic wastes), the trustee should sell the contaminated land for its net value and let the new buyers clean up:

If the property was worth more than the costs of bringing it into compliance with state law, the trustee would undoubtedly sell it for its net value, and the buyer would clean up the property, in which event whatever obligations Kovacs might have had to clean up the property would have been satisfied.

Ohio v. Kovacs, 105 S. Ct. 705, 711 n. 12 (1985); see also Southern Ry. Co. v. Johnson Bronze Co., 758 F.2d 137, 142-43 (3d Cir. 1985) (new buyer held responsible for decontamination); In re Schenck Tours, Inc., 69 Bankr. 906 (Bankr. E.D.N.Y. 1987) (same). Presumably, this dictum is not exhaustive of the trustee's other options.

143. Midlantic Nat'l Bank v. N.J. Dep't of Envtl. Protection, 106 S. Ct. 755, 762-63, reh'g denied, 106 S. Ct. 1482 (1986).

144. 733 F.2d 267 (3d Cir. 1984); see In re Commonwealth Oil Refining Co., 805 F.2d 1175 (5th Cir. 1986) (enforcing environmental injunction even though the public faced no immediate harm).

145. Id. at 273-74. In reaching this conclusion, the court worried (perhaps unduly) that its decision contradicted the holding in Kovacs that such injunctions are "claims" that can be discharged in bankruptcy. Id. at $277 \mathrm{n} .11$. All police-power actions requiring future conduct are claims. The point of section $362(b)(4)$ is that nonbankruptcy standards of socially responsible conduct (which are almost always costly) are not suspended by a bankruptcy petition. Thus, when future conduct is mandated by an environmental injunction, the injunction should not be stayed. See Note, Clean-up Orders and the Bankrupty Code: An Exception to the Automatic Stay, 59 St. JoHN's L. REv. 292, 314-15 (1985). On the other hand, if the environmental hazard has already been eliminated and the government merely desires reimbursement, then the government is seeking only a money judgment, 
describes the trustee's power of sale free of a toxic-waste servitude. Accordingly, no ability to foreclose successor liability for toxic-waste servitudes seems possible. Because of the link between priority and forecloseability, the holding in Penn Terra implies that the toxic-waste servitude survives bankruptcy. ${ }^{146}$

which should be stayed. Cf. In re Revere Copper and Brass, Inc., 32 Bankr. 725, 728 (Bankr. S.D.N.Y. 1983) (enjoining enforcement of fines by private attorney general based on prepetition conduct). In either case, all injunctions against trustees (as successors to contaminated land) are "claims" in bankruptcy; the former category of injunction is entitled to administrative priority, while the latter is not. In re Laurinburg Oil Co., 49 Bankr. 652, 654 (Bankr. M.D.N.C. 1985); In re Distrigas Corp., 66 Bankr. 382 (Bankr. D. Mass 1986).

An interesting feature of Penn Terra is the suggestion that the court issuing the injunction will have jurisdiction over the bankruptcy trustee. See Commonwealth v. First Fed. Corp. (In re First Federal Corp.), 42 Bankr. 682, 684-85 (Bankr. W.D. Va. 1984); In re Kish, 41 Bankr. 620, 623 (Bankr. E.D. Mich. 1984). Alternatively, the bankruptcy court could enforce the injunction, but sections 362(b)(4) and (5) clearly imply that the court issuing the injunction should continue to have jurisdiction. See 11 U.S.C. $\$ 362$ (1982). The logical division of responsibility would require the issuing court to describe the trustee's liability and the bankruptcy court to oversee expenditures of money in response to that liability. See People v. Elec. Util., 41 Bankr. 874, 877 (Bankr. N.D. Ill. 1984). See also First Fed. Corp. at 685 (suggesting that under section 105 of the Bankruptcy Code, the court has discretion to override section 362(b)(4) with an injunction forbidding police-power actions); Eisenberg, Bankruptcy in the Administrative State, LAw \& CoNTEMP. Probs., Spring 1987, at 43 (discussing the conflict between regulatory authority and bankruptcy court jurisdiction).

Sections 362(b)(4) and (5) provide that the following actions are not stayed by the bankruptcy petition:

(4) . . . the commencement or continuation of an action or proceeding by a governmental unit to enforce such governmental unit's police or regulatory power;

(5) ... the enforcement of a judgment, other than a money judgment, obtained in an action or proceeding by a governmental unit to enforce such governmental unit's police or regulatory power....

11 U.S.C. $\$ \S 362(\mathrm{~b})(4)$ and 362(b)(5) (1982) (emphasis added).

146. Thomas Jackson has endorsed the idea that toxic-waste servitudes might result in a high priority for the government, if the government performs postbankruptcy cleanup. See Jackson, Of Liquidation, Continuation, and Delay: Analysis of Bankruptcy Policy and Nonbankruptcy Rules, 60 AM. BANKR. L.J. 399, 419-20 (1986) [hereinafter cited as Jackson, Liquidation, Continuation, and Delay]. His translation of successor liability into a bankruptcy priority, however, leaves a lot to be desired. Jackson states that, when one considers the buyers' successor liability for toxic-waste cleanup,

one will probably conclude that [the] State has the equivalent of a statutory lien on [the contaminated] Site itself, because any owner-whether acquiring title by gift, purchase, or foreclosure, will bear cleanup responsibility. Since the cleanup cost swamps [the] Site's value cleaned up, any owner would willingly give [the] Site to [the] State in exchange for being relieved of the cleanup obligation.

Id. at 419 . In equating servitudes with liens, Jackson mischaracterizes environmental law in two respects: (1) If the toxic-waste servitude is a statutory lien, then the debtor cannot convey a subsequent senior mortgage to some lender. The government, in any subsequent foreclosure sale, should be able to offer title to a buyer that is free and clear of the subsequent mortgage. Yet we saw that such subsequent mortgages do have seniority-when, in the reverse prisoner's dilemma, the mortgagee waits until the government cleans up, seeks reimbursement through a money judgment, and then seeks to sell the decontaminated land as a junior judicial lien holder. See supra text accompanying notes 88-94. (2) If the toxic-waste servitude is an equitable lien, then the trustee should be able to sell land free and clear of this lien whenever the price bid exceeds the value of the government's "lien." See 11 U.S.C.A. \$ 363(f)(3) (West Supp. 1985). Yet environmental law would never permit a trustee to guarantee to subsequent grantees that they do not have to clean up toxic wastes that are present on the land. The whole point of Jackson's article is that the government always has a statutory lien by virtue of nonbankruptcy law. Jackson, Liquidation, Continuation, and Delay, supra, at 419 ("Bankruptcy law, however, has no substantive direction here. One must analyze nonbankruptcy law"). Therefore, to call the EPA a statutory lien creditor involves Jackson in a serious self-contradiction. Cf. In re Stevens, 53 Bankr. 783, 787 (Bankr. D. Me. 1985) (court rejects 
A contrary view has emerged, however, based on the argument that if the toxic wastes were deposited before bankruptcy - and they almost always arecleanup after bankruptcy is to be considered a prebankruptcy (unsecured) claim. Such a view was taken in In re Pierce Coal $\mathcal{E}^{2}$ Construction, Inc. ${ }^{147}$ In that case, a coal mining firm had to post performance bonds for its duty to reclaim strip mined land as a condition for receiving mining permits. All the performance bonds in the Pierce bankruptcy were posted before bankruptcy. Most of the postbankruptcy need to reclaim stemmed from prebankruptcy

argument that Maine's forfeiture rights are a "constructive statutory lien"), rev'd on other grounds, 68 Bankr. 774 (D. Me. 1987).

Jackson's equation of servitudes with equitable liens has an important practical consideration. In cases where the land has a negative value (and where the trustee cannot abandon the land), the government's priority would be limited to the decontaminated value of the land. Under Jackson's view, the government has only a partial priority and, in addition, a powerful incentive to do nothing until the trustee cleans up or until the trsutee sells the land to a solvent buyer. Such a disincentive could harm the public welfare. See United States v. Wade, 546 F. Supp. 785, $792-94$ (E.D.Pa. 1982), appeal dismissed, 713 F.2d 49 (3d Cir. 1983) (criticizing the EPA for doing nothing and relying on its injunctive powers to make the defendant clean up). Under my view, if the trustee must retain the land because she cannot abandon it, the government (if it performs the cleanup in lieu of the trustee) gets a priority for the entire amount of the cleanup.

Jackson's equation of the toxic-waste servitude with statutory liens is clumsy scholarship at best, but his further remarks-that environmental law creates a complete restraint on the debtor's power of alienation-are completely unsupportable:

[The] State might have more [than a statutory lien]. As a matter of nonbankruptcy law, it may be able to prohibit any distribution of any of [the] Firm's assets in a dissolution to any creditor unless and until [the] Site is cleaned up. If so, [the] State has the equivalent of a statutory lien on all of the [the] Firm's assets. This case becomes similar to Chicago Board of Trade [v. Johnson, 264 U.S. 1 (1924)], because no one has any rights to [the] Firm's assets until [the] State has gotten its pound of flesh. But the determination of whether [the] State has superior rights to all of [the] Firm's assets . . . is an issue to be resolved by nonbankruptcy law, not by bankruptcy policy.

Id. at 419-20 (footnotes omitted). Permit me to translate. In Chicago Board of Trade, the debtor held a membership in a commodities trading floor. A condition of transferring membership was that the seller's debts to all other members be paid in full. The Supreme Court upheld this disability to alienate. Therefore, the trustee had the choice of meeting the conditions for alienation (paying off the creditors) and selling the membership, or, if the condition was too onerous, simply abandoning the membership. A power to prevent alienation is different from a lien, in that the power does not allow the owner of the power to foreclose on the item affected. It simply allows the owner of the power to prevent the debtor from alienating the encumbered item. See Chicago Board of Trade, supra, at 8 ("The right of the objecting creditor members differs, however, from the common law lien, in that the latter, to exist and be effective, must deprive the owner of possession and enjoyment, whereas the former is consistent with possession and enjoyment by the owner, and only interferes with, and prevents, alienation"). A power to restrain alienation also differs from a servitude in that a restraint on alienation never makes a buyer of the encumbered item personally liable. Rather, it prevents the existence of buyers in the first place.

Jackson therefore muddles the matter when he characterizes restraints on alienation (such as the one in Chicago Board of Trade) as the "equivalent" of a statutory lien. But, even worse, he suggests that New Jersey law creates a power to restrain alienation on behalf of the state of New Jersey. See Jackson, Liquidation, Continuation, and Delay, supra, note 146, at 419 n. 59 (citing N.J. ANN. \& 58:1023.11.f. (West Supp. 1986)). Nothing could be further from the truth. This section does create a floating statutory lien on all the debtor's property, id. $\S 58: 10-23.11 . f . f$, but it does not prohibit the alienation of all the debtor's property.

Jackson's project in Liquidation, Continuation, and Delay, supra, is to convince bankruptcy judges that they should never act on their equitable impulses and should limit their task to finding what state law is; when state law is found, it should be translated into the bankruptcy context. Yet when Jackson himself tries to recapitulate specific state laws, Jackson invariably makes a complete hash of it.

147. 65 Bankr. 521 (Bankr. N.D.W.Va. 1986). 
mining. When the debtor-in-possession terminated its business (without having reclaimed very much land), the state of West Virginia immediately demanded and received payment from the surety.

The surety then requested high-priority reimbursement for its forfeitures to West Virginia. The court was probably right in denying this request. No reclamation had actually occurred at the time of the request. Administrative priority should be awarded for services actually performed, not for services not yet performed (without, at least, some strong assurance that the services would some day be performed).

The reason given for denying the request for high-priority reimbursement, however, was that the prospective need to reclaim land was really (for the most part) a prebankruptcy expense because most of the land to be reclaimed was torn up before bankruptcy. ${ }^{148}$

This analysis resonates with the "acceleration" effect that bankruptcy has on unmatured claims, but it ignores the fact that if reclamation of land is a prebankruptcy (low-priority) expense, then the public authorities who clean up (at a low priority) simply transfer a great deal of wealth to the bankrupt estate. This failure to get high-priority reimbursement gives the government every incentive to wait until the trustee sells the damaged land to a solvent landowner. The government can then compel the solvent landowner to clean up. The government's incentive to delay enforcement seems like a bad thing in emergency cases. Moreover, the creditors of the debtor are indifferent between waiting for a solvent buyer to appear and letting the government clean up immediately (at a high priority). For that reason, the "timing" assumptions in the Pierce case should be rejected. Instead, the presence of an unforecloseable toxic-waste servitude on property of the estate should lead to

148. Id. at 530 ("prepetition expenses occasioned by the prebankruptcy debtor are not entitled to administrative priority.... [T] his Court is not empowered with the authority to change the priorities as enacted by Congress"). See also Jackson, Liquidation, Continuation, and Delay, supra note 146, at 420. Jackson's defense of the prepetition nature of the trustee's postbankruptcy breach of an ongoing duty to clean up is based on a mind game wherein we are supposed to imagine that chapter 7 liquidations occur instantaneously. According to the rules of this mind game, one microsecond after a bankruptcy petition is filed, all assets are magically liquidated and all creditors are magically paid. With this whimsical Coase-like assumption in mind, Jackson writes:

Note, too, that [the] State's claim for a cleanup is clearly prepetition. The bankruptcy proceeding, under our current assumption, is instantaneous, and [the] Firm has no postbankruptcy existence. In such a world, there can be no postpetition claims against [the] Firm; it therefore makes no sense to consider this cleanup order as anything other than a prepetition claim.

Id. at 420 . In chapter 11 reorganizations, however, the "instantaneous liquidation" assumption does not apply, according to Jackson, so that the government would get a high priority there.

I fail to appreciate this "logic." True, in a world with no postbankruptcy claims, all claims must, by process of elimination, be prebankruptcy claims. How does this prove that we, condemned as we are to a world in which postbankruptcy claims are possible, should follow the rule Jackson deduces from his fantasy world?

I should add that Jackson's "prebankruptcy" characterization is supplemented with the view that the reaction of buyers in liquidation sales should influence priority, so that he is not exactly proposing that environmental claims should always have low priorities in chapter 7 liquidations. Jackson's use of the buyer's strategic reaction to successor liability is critiqued supra in note 146. 
the conclusion that the government should receive a high-priority claim in bankruptcy.

b. Nonservitude Cases. The concept of postbankruptcy cleanup as an administrative expense generated by unforeclosed toxic-waste servitudes helps to reconcile some cases where injunctions were dissolved and administrative superpriorities were not permitted. In an earlier opinion in the Kovacs bankruptcy, an injunction against Kovacs personally had been dissolved. ${ }^{149}$ It was not Kovacs, but the company of which he was president that owned the contaminated land, and his trustee never took possession of it. 150 Since Kovacs's liability was thus strictly personal and unrelated to a toxic-waste servitude, an environmental injunction against him (or, presumably, his trustee) was appropriately stayed by the bankruptcy petition. ${ }^{151}$

Similarly, a debtor who files for bankruptcy may have promised to clean up someone else's land. At this point, such an obligation is totally unconnected with a toxic-waste servitude. ${ }^{152}$ Because the trustee is not the owner of the encumbered land, he inherits no servitude liability, and any claim for breach of contract by the owner of the contaminated land is simply an ordinary claim in the debtor's bankruptcy. ${ }^{153}$

149. See In re Kovacs, 681 F.2d 454, 455 (6th Cir. 1982), vacated, 459 U.S. 1167 (1983).

150. Id. at $455-56$.

151. Id. at 456; see Note, Bankruptcy, Hazardous Waste and Mass Tort: A Top Prionity Review, 23 Houston L. REv. 1243, 1250 (1986).

152. An exception to this general rule is New Jersey, the world center of toxic wastes, which imposes a toxic-waste servitude on a factory in favor of a neighboring land owner whose land the factory pollutes. See Dep't of Transp. v. PSC Resources, Inc., 175 N.J. Super. 447, 470, 419 A.2d 1151,1164 (Law Div. 1980). See supra notes 64-77 and accompanying text. In deciding whether or not to foreclose such a servitude, bankruptcy courts should analogize to the treatment of the California-style products-liability servitude. That is, foreclosure should be possible unless some form of priority was actually intended by the creator of this servitude.

153. See Southern Ry. Co. v. Johnson Bronze Co., 758 F.2d 137, $141-42$ (3d Cir. 1985). In Southern Railway, a creditor upon whose property the debtor dumped toxic wastes (pursuant to a license) claimed to have a servitude on the debtor's leasehold, but the Third Circuit declared that no such servitude existed under South Carolina law. Id. at 140. The court went on to say that cases such as In re Quanta Resources Corp., 739 F.2d 912 (3d Cir. 1984), aff'd, 106 S. Ct. 705, reh'g denied, 106 S. Ct. 1482 (1986), and Penn Terra provided no guidance on the priority question. 758 F.2d at 142-43. In fact, the court said, somewhat mysteriously, that

the Supreme Court has spoken definitively on the priority question in Ohio v. Kovacs, [105 S. Ct. 705 (1985),] and that case controls. The bankruptcy court had no authority to elevate [a] general unsecured contract indemnity claim to the status of a claim secured by a lien on the proceeds of the sale from [debtor] to [buyer].

758 F.2d at 142; see In re Pierce Coal \& Const., Inc., 65 Bankr. 521 , 529 (Bankr. N.D.W.Va. 1986) ("this Court cannot find this determination in ... Kovacs"). The Southern Railway court, however, did not consider the connection between priority and the toxic-waste servitude for pollution on one's own land. If it had, it undoubtedly would have edited out such dicta.

The debtor in Southern Railway also dumped some toxic wastes onto the debtor's own leasehold. This leasehold was transferred to a buyer (Perry), who later claimed an administrative priority in the debtor's bankruptcy, on the grounds that the debtor had defrauded Perry by failing to disclose the existence of the toxic wastes. The bankruptcy court disagreed; the toxic wastes were not concealed and, in effect, Perry should have reimbursed itself by deducting the cost of cleanup from the purchase price. Id. at 142 ("under the circumstances Perry, an experienced buyer and seller of 
Finally, a debtor may have leased land on which the bankrupt tenant has deposited toxic wastes. If the trustee in the tenant's bankruptcy assumes the lease, the trustee will have to clean up at a high priority. In such a case, the trustee's position is identical to that of the trustee for a fee owner. In other words, continued use of the land renders the trustee liable (at a high priority) for cleanup. Alternatively, the sale of the lease guarantees that the buyer of the lease will discount the price by the expected amount of the cleanup liability, an amount that equates with high priority for cleanup. If, however, the trustee rejects the lease, he cannot use the premises or sell the lease to a discounting buyer; instead, the land reverts to the landlord, who will be charged with the cleanup liability. In such a case, the cleanup no longer has any connection with future sale or use by the trustee, and because there is no connection, creditors are no longer indifferent about high priority (and discounted sale to a buyer who must clean up). It follows, therefore, that the landlord should not receive an administrative priority for its prospective or accrued cleanup expense. ${ }^{154}$

c. Intertemporal Inequalities. The matter of high priority and unforecloseability of toxic-waste cleanup costs (when the bankrupt estate actually owns the contaminated land) is simple enough, but it raises issues of intertemporal creditor priority. By forcing the trustee or buyer to clean up

industrial sites, should have made additional inquiries"). The court, id. at 142 , cited Ohio v., Kovacs, 105 S. Ct. 705 (1985), for this proposition. According to the Kovacs case:

If the property was worth more than the costs of bringing it into compliance with state law, the trustee would undoubtedly sell it for its net value, and the buyer would clean up the property, in which event whatever obligation [the debtor] might have had to clean up the property would have been satisfied.

$105 \mathrm{~S}$. Ct. at 711 n.12.

154. In re Dant \& Russell, Inc., 61 Bankr. 668, 670 (Bankr. D. Ore. 1985), aff'd, 67 Bankr. 360 (Bankr. D. Ore. 1986) ("It is pure sophism and offensive to the rights of other secured creditors to use ... the debtor's post-filing occupancy ... to transform the claim into an administrative claim.").

In In re Wall Tube \& Metal Prods. Co., 56 Bankr. 918 (Bankr. E.D. Tenn. 1986), the court got these issues half-right. There, a tenant having left behind numerous barrels containing toxic wastes, went bankrupt. Id. at 920-21. By agreement with the landlord, the trustee obtained the landlord's commitment to clean up the remaining toxic wastes in exchange for a conveyance of the leasehold and some fixtures back to the landlord. Id. at 921-22. The tenant, however, remained the owner of some barrels containing toxic wastes. Id. at 922-23. Thereafter, the state of Tennessee spent $\$ 23,000$ on cleanup and sought an administrative priority for the expense thus incurred. Id. at 920 . The court, however, concluded that money expended to clean up property of a nondebtor (i.e., the landlord) was not an administrative-expense claim, a conclusion which seems totally appropriate. Id. at 923-24. Since the trustee no longer had rights in the land at the time of the cleanup, he could no longer enter upon it to effect a cleanup; accordingly, the only conceivable assistance he could have offered was reimbursement, and reimbursement claims properly should be treated as ordinary claims in bankruptcy. The court further went on to rule that the money expended by the government to clean up the debtor's property (the remaining barrels of toxic waste) also was not an administrative expense on the ground that the cleanup simply did not help preserve the estate. Id. at 924-25. This holding seems no longer tenable after Midlantic Nat'l Bank v. N.J. Dep't of Envtl. Protection, 106 S. Ct. 755, 762, reh'g denied, $106 \mathrm{~S}$. Ct. 1482 (1986), holding that trustees must clean up the property of the estate (at least in the case of imminent environmental threats) even if the creditors may be prejudiced by such expenditures. Because the trustee must assume responsibility, cleanup costs must be accorded administrative-expense status; and when the government volunteers to undertake this task, its claim similarly should be accorded administrative-expense priority. Were it otherwise, the government would have an incentive to do nothing until the trustee acts. 
the land or by cleaning it up itself on a priority basis, the government (standing in for future tort victims) essentially obtains a one hundred percent recovery on its "claim." In such cases, the debtor's estate is pro tanto reduced, and this prejudices the recovery of the general creditors, some of whom may themselves be tort victims of the very toxic wastes at issue. In a very real sense, then, present tort victims are subsidizing the toxic-waste cleanup, a preventive measure taken on behalf of potential future tort victims.

Surely there are better solutions to this problem. For instance, if "investing" creditors were subordinated to cleanup costs while victims of the toxic wastes were not, the subsidization by present victims of future remedial actions would be reduced. ${ }^{155}$ One reads more and more appeals for favoring tort victims over contract creditors, ${ }^{156}$ but courts have been unwilling to rearrange priorities in such a general way, observing that equitable subordination principles cannot be used to amend the Bankruptcy Code. ${ }^{157}$ Assuming that such an attitude persists, the choice between foreclosing or not foreclosing successor liability for toxic wastes becomes a political issue as to who should bear the costs of cleanups: the general creditors (including tort creditors) of the debtor or the public. ${ }^{158}$

155. See Note, Victim Compensation, supra note 44, at 612.13 (investors should be held liable for toxic-waste costs).

156. See Halpern, Trebilcock \& Turnbull, An Economic Analysis of Limited Liability in Corporate Law, 30 U. Toronto L.J. 117, 149 (1980); Schwartz, Products Liability, Corporate Structure, and Bankruptcy: Toxic Substances and the Remote Risk Relationship, 14 J. Legal STUD. 689, 717 (1985); Shuchman, An Attempt at a "Philosophy" of Bankruptcy, 21 UCLA L. REv 403, $431-32$ (1973); Stone, The Place of Enterprise Liability in the Control of Corporate Conduct, 90 YALE L.J 1, 68-76 (1980); Developments, supra note 74, at 1597-99; Note, Tort Creditor Priority in the Secured Credit System: Asbestos Times, the Worst of Times, 36 Stan. L. Rev. 1045 (1984); Note, Bankruptcy, Product Liability, and Hazardous Waste, 6 VA. J. NAT. Res. LAW 179, 197-212 (1986). In railroad reorganizations, such claimants are accorded a priority. 11 U.S.C. $\$ 1171$ (a) (1982).

157. Machinery Rental v. Herpel (In re Multiponics, Inc.,) 622 F.2d 709, 713 (5th Cir. 1980) ("Equitable subordination . . must not be inconsistent with the provisions of the Bankruptcy Act"); In re T.P. Long Chem., Inc., 45 Bankr. 278, 287 (Bankr. N.D. Ohio 1985); DeNatale \& Abram, The Doctrine of Equitable Subordination as Applied to Nonmanagement Creditors, 40 Bus. LAw. 417, 447-48 (1985); see also In re Oklahoma Refining Co., 63 Bankr. 562, 565 (Bankr. W.D. Okla. 1986) (implying that secured parties claiming uncontaminated assets have no obligation to contribute to toxic-waste cleanup).

158. The Supreme Court was unfairly made to wear the dunce cap in Note, Cleaning Up in Bankruptcy: Curbing Abuse of the Federal Bankruptcy Code by Industrial Polluters, 85 Colum. L. REv. 870, 876-77 (1985) [hereinafter Columbia Note]. The author of this Note complains that owing to the Court's failure in Ohio $v$. Kovacs to clarify the effect of the automatic stay on cleanup obligations of the trustee (as owner of contaminated land), there will be increased abandonment of contaminated land by trustees who do not want to clean up. Id. This criticism fails for two reasons. First, the question of the automatic stay was not presented to the Court; but even so, the Court cited the Penn Terra case (holding that orders to clean up were not stayed) with approval. Kovacs at $711 \mathrm{n} .11$. This is all the extracurricular guidance that Supreme Court etiquette permits. Second, increased abandonment (if allowed) is not a likely strategic reaction to the alleged uncertainty created; instead, trustees will abandon contaminated land only if it is unprofitable to clean up. See New Jersey Dep't of Envt'l Protection v. Nat'l Smelting of N.J., Inc. (In re Nat'l Smelting of N.J., Inc.), 49 Bankr. 1012, 1014-15 (D. Colo. 1985) (criticizing the bankruptcy court for making no findings on profitability). Indeed, the alleged uncertainty seems to have no discernible impact on the decision to abandon. Curiously, the author of the cited Note later advocates amendments to the Bankruptcy Code that would permit abandonment, Columbia Note, supra, at 884-87, apparently condoning a strategic reaction that he earlier had denounced. There seems to be some inconsistency here. 
2. Cases in Which Cleanup Costs Exceed the Uncontaminated Land Value but not the Value of the Bankrupt Estate: $(e>[c-f]>[v-m])$. Prior to the toxic-waste crisis, courts rarely considered what to do with property that has a negative value. ${ }^{159}$ But land contaminated by toxic wastes often has a negative valuethat is, the owner must spend more for cleanup than the land (after decontamination) is worth.

Where contaminated land has such a negative value, the trustee's thoughts surely will turn to abandonment. As any teacher of a basic property course knows, the word "abandonment" is much abused. Let us start, therefore, by considering the numerous different connotations that have been assigned to the word. First, in Hohfeldian terms, abandonment means the empowerment of any stranger to take title that is good against the claims of the abandoner. ${ }^{160}$ In light of a common law tradition that insists on someone having seizin, abandonment does not terminate the owner's title until some stranger asserts a better title.

Second, bankruptcy courts, when they use the term "abandonment," have in mind something different from the Hohfeldian definition. In bankruptcy, abandonment never authorizes a stranger to take title. Rather, abandonment is simply a renunciation of the trustee's present possessory rights. Once those rights are over, the "future interests" of other parties become presently possessory. These parties include unforeclosed lien creditors and the debtor herself. 161

The second definition was used by the Supreme Court in Ohio v. Kovacs, 162 when it said:

If the property were worth less than the cost of clean-up, the trustee would likely abandon it to its prior owner, who would have to comply with the state environmental law to the extent of his or its ability. ${ }^{163}$

159. See Simonton, Abandonment of Interests in Land, 25 ILL. L. REv. 261, 263 (1930) ("As to possessory interests in land there has been no need felt for any doctrine of abandonment as a means of termination"). For the few cases in which negative value is discussed, see Columbia Note, supra note 158 , at $885-86$.

160. Hohfeld defined abandonment in this way:

Thus, X, the owner of ordinary personal property "in a tangible object" has the power to extinguish his own legal interest... through that totality of operative facts known as abandonment; and-simultaneously and correlatively-to create in other persons privileges and powers relating to the abandoned object-e.g., the power to acquire title to the latter by appropriating it.

W. Hohfeld, Fundamental Legal Conceptions as Applied in Judicial Reasoning and Other LEGaL EsSays 51 (1923) (footnote omitted).

161. "Abandonment of an asset divests the trustee of his title ... Revestment of the title to abandoned property in the bankrupt is the corollary of divestment of the trustee." 4 A Collier ON BaNkRUPTCY \& 70.42(4), at 512-13 (L. King ed. 1978).

In light of the fact that strangers will not volunteer to take up negative-value land, Ohio has an interesting provision authorizing the state environmental protection agency to take conveyances of negative-value land. OHIo Rev. Code ANN. $\$ 3734.23$ (Supp. 1986). Among the benefits of this empowerment is the prospect that the government, having cleaned up the land, can perhaps recoup the expense by selling the land, which would have become more valuable. Id. at $\$ 3734.24$.

162. 105 S. Ct. 705 (1985).

163. Id. at $711 \mathrm{n} .12$. 
A third meaning ${ }^{164}$ is an eccentric one: Abandonment means terminating the personal liability of a landowner under environmental law by conveying away contaminated property. This eccentric meaning was used by the Supreme Court when it stated in Midlantic National Bank $v$. New Jersey Department of Environmental Protection ${ }^{165}$ that abandonment is "in contravention of a state statute or regulation that is reasonably designed to protect the public health or safety from identified hazards." 166 In fact, abandonment in the first or second sense is permitted under environmental law. What environmental law does not permit is the termination of the landowner's liability by means of conveying the property away. ${ }^{167}$

Based on the above semantic confusion, the majority of the Supreme Court reversed field (by a five-to-four vote) from its pro-abandonment dicta in Kovacs. The Midlantic majority engaged in the following reasoning: (1) Environmental law prohibits abandonment in the third sense. (2) Bankruptcy courts are bound by the commands of environmental law (at

164. In his contribution to this symposium, Douglas Baird uses the word abandonment to mean three different things at different parts of his article. First, abandonment is used in the first (Hohfeldian) sense of empowering another to take title. Baird, World Without Bankruptcy, supra note 116, at 189 ("Debtor may not be able to escape the obligations of ownership unless it can find someone else to assume them."). Second, abandonment is used in the third sense: the ability of a person to terminate a personal liability to clean up. Id. at 190 ("If a firm outside of bankruptcy cannot rid itself of obligations that arise out of continuing ownership of a waste dump, a firm inside should not be able to rid itself of these continuing obligations either.").

Baird adds yet another definition of abandonment: abandonment means simply walking away from a problem and refusing to deal with it, as in "Johnny abandoned his piano playing and turned on the television set." This new (fourth) definition misleads Baird into suggesting that the Midlantic case was moot. ("The issue may have been moot . . . . [T] abandoned."). Id. at 188-89. The trustee had abandoned the property only in Baird's sense, but not in the three earlier senses. Hence, Baird's conclusion of mootness is a direct result of his semantic confusion.

On the mootness point, Baird writes,

In its recounting of the facts, the Court noted several times that the dump sites had already been abandoned. ... [T] [Te dumps did not seem to pose a continuing hazard because the state had already cleaned them up. What difference would it have made if the Court had ruled that the trustee could abandon the property? .... If it would make no difference, there might not have been a case or controversy.

Id.

I have long believed that the telephone is underutilized in legal scholarship. On June 5, 1986, I telephoned Norman Spiegel, the attorney who argued the case to the Court of Appeals for the Third Circuit for the New York Attorney General's office, and he reported that the land continues to have serious subsoil pollution that needs to be rectified. Since the trustee cannot abandon the land, highpriority liability for further cleanup will continue. Therefore, the case is definitely not moot. Cf. Note, The Bankruptcy Shield: Using Bankruptcy Law Under Ohio v. Kovacs to Avoid Compliance with Environmental Enforcement Obligations, 14 CAP. U.L. REV. 631, 639-41 (1985) (arguing that soil, as opposed to surface contamination, kept the Kovacs case from being moot).

165. 106 S. Ct. 755, reh'g denied, 106 S. Ct. 1482 (1986).

166. Id. at 762 (footnote omitted).

167. 42 U.S.C. $\$ 9607$ (e)(1) (1982) ("No . . . conveyance shall be effective to transfer from the owner . . liability imposed under [CERCLA]"). See also In re Quanta Resources Corp., 739 F.2d 912, 921-23 (3d Cir. 1984) (concerning abandonment by a trustee in bankruptcy), aff' $d$ sub nom. Midlantic Nat'l Bank v. N.J. Dep't of Envtl. Protection, 106 S. Ct. 755, reh'g denied, 106 S. Ct. 1482 (1986); In re Pierce Coal \& Const., Inc., 65 Bankr. 521 (Bankr. N.D.W.Va. 1986) ("the debtor's estate was liable to the EPA under CERCLA irrespective of an abandonment by the trustee"). 
least in emergencies). ${ }^{168}$ (3) Therefore, bankruptcy courts may not authorize abandonment in the second sense. Note the radical discontinuity between the first and third propositions.

This critique of the reasoning actually used in Midlantic is not to say that the Supreme Court reached the wrong result. If the task is to find out what Congress intended about abandonment and the toxic-waste crisis, there is a good argument that if Congress had anticipated the toxic-waste issue, Congress would have looked to the debtor's estate as a source of funding cleanup. ${ }^{169}$ Although some have commented that the issue of "who pays" is an arbitrary one and not a proper bankruptcy question, ${ }^{170}$ the fact is that without prompt and immediately available funding, the environment and the public could suffer irremediable damage and escalating costs in the future. If courts allow bankruptcy estates to go to creditors instead of environmental cleanup, it is not obvious that the public could organize itself to replace the lost funding.

In any case, the Midlantic National Bank opinion decided remarkably little about the trustee's power of abandonment. For instance, the holding in Midlantic National Bank cannot mean that a trustee may not abandon negativevalue land under any circumstances, but only that she may not do so until she has first depleted the bankrupt estate in pursuit of cleanup. Midlantic National Bank is, therefore, not really about abandonment at all, but rather is a pure

168. "Congress did not intend for the Bankruptcy Code to pre-empt all state laws that otherwise constrain the exercise of a trustee's powers." $106 \mathrm{~S}$. Ct. at 762.

169. The issue between the majority and minority was fought out entirely on the unrealistic assumption that Congress actually intended to articulate a specific toxic-waste rule when it enacted a broad abandonment power for the trustee. See 11 U.S.C.A. \$ 554(a) (West Supp. 1985) ("After notice and a hearing, the trustee may abandon any property of the estate that is burdensome to the estate or that is of inconsequential value to the estate"). The majority concluded that Congress intended to codify the scant case law of abandonment that had developed prior to the Bankruptcy Code which denied the trustee authority to abandon negative-value land. $106 \mathrm{~S}$. $\mathrm{Ct}$. at 767-68. The minority, on the other hand, thought the plain language of the statute permitted abandonment of even negative-value land. Id.

A more realistic approach would have been to acknowledge that Congress had no actual intent at all, because it had not anticipated the toxic-waste crisis. Therefore, it is necessary to reconstruct what Congress would have done. If that reconstruction is impossible, then the Supreme Court might have adopted the policy that is most consistent with the national interest. An anti-abandonment rule (and the corollary high priority in bankruptcy for postbankruptcy cleanup) seems just that, based on what I know.

170. Thomas Jackson asks rhetorically whether environmental injunctions should be enforced in bankruptcy and responds:

The answer should be no, because the issue of the public's health and safety is largely a red herring in the case of a liquidating corporation. The question is not whether the toxic waste site should be cleaned up; it is simply a question of who pays for it. [I] $\mathrm{f}$ the automatic stay [protects a trustee from having to decontaminate land], the state can spend its own money to clean up the site, and then file a claim in [the] bankruptcy proceeding.

Jackson, Liquidation, Continuation, and Delay, supra note 146, at 423 . Such a view might be defensible if infinite funds were readily available from the government to perform a cleanup, but the funds are not always there, and any delay in raising the funds (if they ever are raised) could be very harmful to the public. The public's health and safety is no red herring. The cruelty of cancer, birth defects, and the like are real. Jackson's formal system for deriving "neutral" answers for bankruptcy disputes is the red herring. 
and simple priority case that establishes a nonstatutory superpriority for the government's rights under the toxic-waste servitude. ${ }^{171}$

Once again, it is to be hoped that retention of contaminated land by the trustee pending cleanup does not exhaust all remedial possibilities. For example, it might be preferable for the trustee to pay a more efficient decontaminator to take title to negative-value land when to do so would cost less than the amount that the trustee would otherwise have to spend to clean up the land. ${ }^{172}$ Such assumption agreements would be analogous to those that the FDIC makes with third parties to take over insolvent banks, under which the FDIC engages to subsidize the buyer of the insolvent bank if the buyer will assume the bank's liabilities. ${ }^{173}$

Several post-Midlantic courts have also decided that Midlantic applies only to environmental emergencies, but not to environmental hazards that need no immediate attention. ${ }^{174}$ Under this view, abandonment (in the second sense) will frequently be possible. The effects of such abandonment will be to divest the trustee of land and to reinvest the debtor with the land.175 The abandonment does not terminate the liability of the estate for cleanup, ${ }^{176}$ since all former landowners remain liable even after their conveyances. But the status of the liability will have changed radically. Before, high priority for reimbursement claims was based in part on the existence of a toxic-waste servitude implied on land actually within the bankrupt estate. The servitude implied that the creditors would be roughly indifferent between a sale of contaminated land to a buyer, on the one hand, and cleanup, followed by the sale of decontaminated land to a buyer, on the other. The idea was that, given creditor indifference, high priority in bankruptcy for the government removed an incentive that the government would otherwise have to wait and do nothing until a solvent third party buyer bought the land.

171. One must not overestimate the difference in impact on creditors of landowners. The loss imposed on creditors by the Midlantic National Bank decision is the total amount of cleanup cost (not chargeable to secured creditors under 11 U.S.C. $\$ 506$ (c) (1982)) minus the value of decontaminated land-i.e., $(c-f-v)$, where $[f<v]$. If $[f>v]$, then apparently the secured parties are privileged to walk away. See In re Quanta Resources, Inc., 739 F.2d 912, 924-25 (3d Cir. 1985) (suggesting that mortgagees had been permitted to walk away from decontaminated land), aff'd sub nom. Midlantic Nat'l Bank v. N.J. Dep't of Envtl. Protection, 106 S. Ct. 755, reh'g denied, 106 S. Ct. 1482 (1986).

172. See In re Wall Tube \& Metal Prods. Co., 56 Bankr. 918, 922-23 (Bankr. E.D. Tenn. 1986).

173. See generally Bransilver, Failing Banks: FDIC's Options and Constraints, 27 AdmIN. L. Rev. 327 (1975).

174. In re Pierce Coal \& Const., Inc., 65 Bankr. 521, 527, 530-31 (Bankr. N.D.W.Va. 1986) (“After reviewing the Kovacs case and the Midlantic case, this Court concludes that the question of priority status for every environmental clean-up cost has not been answered by the United States Supreme Court"); In re Franklin Signal Corp., 65 Bankr. 268, 272 (Bankr. D. Minn. 1986) ("The trustee only needs to take adequate precautionary measures to ensure that there is no imminent danger to the public as a result of abandonment"); In re Oklahoma Refining Co., 63 Bankr. 562 (Bankr. W.D. Pa. 1986) ("Midlantic requires the bankruptcy court, in determining whether to permit abandonment, to take state environmental laws and regulations into consideration"); Note, Florida's Troubled Phosphate Companies: Can Bankruptcy Law Be Used to Relieve their Obligation to Reclaim the Land?, 38 U. FLA. L. REV. 283, 298-99 (1986); but see In re Commonwealth Oil Refining Co., 805 F.2d 1175 (5th Cir. 1986) (enforcing environmental injunction even though no imminent threat existed).

175. The effects of abandonment on the debtor will be discussed in the next section.

176. See supra note 167. 
If abandonment is allowed (on the grounds that the environmental hazard poses no imminent danger), this rationale is no longer true. The creditors, if they are profit-maximizing, would very much oppose a high priority to the government for cleanup of someone else's land. Therefore, whenever the trustee is permitted to abandon, the government's claim for cleanup reimbursement ought to be demoted from a high-priority to a low-priority claim. ${ }^{177}$ Abandonment of contaminated land would then very much resemble the rejection of an executory contract. If the contract (viz. contaminated land) is assumed (viz. not abandoned), the creditor gets highpriority treatment. ${ }^{178}$ If the contract (viz. contaminated land) is rejected (viz. abandoned), the creditor is demoted to mere equality with his fellows. ${ }^{179}$

\section{Cases in Which Cleanup Costs Exceed the Value of the Bankrupt Estate: $(e<$} $[v-m]<[c-f])$. Sometimes the entire bankrupt estate is insufficient to finance decontamination of the land. Under these circumstances, the trustee will obviously have to abandon the land after all, in spite of the bold statements in the Midlantic National Bank opinion. ${ }^{180}$ Since only two courts have published opinions on this situation so far, ${ }^{181}$ some discussion of the possibilities might be helpful.

177. Cf. In re Stevens, 53 Bankr. 783, 787-88 (Bankr D. Me. 1985) (basing low priority for the state of Maine on the power of the trustee to reject negative-value property). In light of Midlantic, Stevens has now been reversed by the district court, 68 Bankr. 774 (D. Me. 1987).

178. 11 U.S.C.A. § 365 (b)(1) (West Supp. 1985).

179. Id. $\$ 502(\mathrm{~g})$. Another argument that has been made is that, once the trustee abandons the land, the trustee no longer has access to the land in order to clean up the toxic wastes. Therefore, no injunction would be effective against the trustee. In re Kovacs, 681 F.2d 454, 455 (6th Cir. 1982), vacated, 459 U.S. 1167 (1983). This argument is highly disingenuous. Most landowners would probably welcome any stranger onto the land for the purpose of removing hazardous toxic wastes.

180. In re Oklahoma Refining Co., 63 Bankr. 562 (Bankr. W.D. Pa. 1986) (permitting abandonment). The Oklahoma Refining court had this to say about the broad anti-abandonment holding in the Supreme Court's Midlantic opinion:

The trustee thus finds himself confronted with a formidable dilemma. On one hand he has no funds which are not cash collateral [belonging to secured parties] but, under a strict reading of Midlantic, could be required to comply with State laws and regulations which is impossible because of section 363(c)(3) [requiring court approval for use of cash collateral]. We do not believe the Supreme Court intended to place bankruptcy trustees in such a predicament but rather that Midlantic requires the bankruptcy court, in determining whether to permit abandonment, to take state environmental laws and regulations into consideration. Id. at 565 .

181. Id.; In re Franklin Signal Corp., 65 Bankr. 268, 272-73 (Bankr. D. Minn. 1986). In both these cases, the bankruptcy courts chose to develop a rule whereby the trustee could still abandon negative-value land, so long as the toxic-waste contamination presented no imminent health hazard. Since, in both cases, the court found no such imminent hazard, the trustee was allowed to abandon the negative-value property.

This rule is not really applicable to cases in which the cost of cleanup exceeds the entire value of the estate. In such cases, the trustee must abandon whether the toxic wastes are imminently dangerous or not. Rather, it applies whenever abandonment is a discretionary matter.

We have not yet had a case in which the court felt compelled to find that the toxic-waste contamination posed an imminent health risk and the entire bankrupt estate could not cover the cost of cleanup. When the issue is finally presented, the court will have to order the trustee to spend down the bankrupt estate, so that as much cleanup as possible can be achieved. The spend-down, however, should be limited to an amount that still permits the trustee to recover her other expenses. Otherwise, no one would be willing to be a trustee. Compensation of trustees is probably the one rule without which bankruptcy could not exist. See Thomas Solvent Co. v. Kelley (In re Thomas 
a. Individual bankruptcies. It has been noted that since abandonment in bankruptcy usually means that the trustee renounces her right to the contaminated land, the debtor's rights become possessory. According to the Kovacs court, "[i]f the property was worth less than the cost of cleanup, the trustee would likely abandon it to its prior owner, who would have to comply with the state environmental law to the extent of his or its ability."182

This dictum creates a dramatic conflict between the unforecloseable toxicwaste servitude and the debtor's right to a discharge from personal liability. When negative-value land is abandoned to its former owner, he is revested with seizin and reassumes liability on the toxic-waste servitude notwithstanding the federal policy of fresh start after bankruptcy, which apparently does not extend to him. This result is, among other things, ironic. In Kovacs, it will be recalled, when the state of Ohio suggested that injunctive orders were not dischargeable claims, the Court made much of the fact that toxic-waste claims were not listed in section 523(a) of the Bankruptcy Code and that Ohio, therefore, was urging the Court to engage in unauthorized legislation. ${ }^{183}$ Yet, by ruthlessly pursuing the logic of servitudes to the bitter end, the Supreme Court itself has just as effectively amended section 523(a) to deny individual debtors a fresh start.

Bankruptcy abandonment doctrine was invented in an era when property was either valuable or merely worthless. Negative-value property was extremely rare. Now that the toxic-waste crisis has made negative-value property much more common, there is a good argument for recharacterizing bankruptcy abandonment. Instead of holding abandonment to be a trustee's renunciation of presently possessory rights, with the debtor holding a kind of executory interest in the surplus, the debtor could easily be viewed as having been divested of her property altogether. Therefore, once a trustee elects to abandon negative-value property, the trustee does not merely renounce presently possessory rights. In addition, the trustee reconveys the property back to the debtor as if it were a gift. Donees may refuse gifts and bequests. ${ }^{184}$ If, just prior to abandonment, the debtor has no interest in the abandoned negative-value land, abandonment is merely a gift, and the debtor is free to refuse it. By doing so, the debtor could avoid the toxic-waste servitude. Such a recharacterization would vindicate the debtor's fresh start policy.

The recharacterization is not very artful. If it is true that the debtor has no interest in property conveyed by the debtor to the trustee by virtue of

Solvent Co.), 44 Bankr. 83, 88 (Bankr. W.D. Mich. 1984) (“If a governmental unit can completely deplete all of the funds in an estate, or if the trustee cannot abandon an asset for the benefit of the creditors, how can a court find a trustee willing to serve without pay or allowance"?).

182. Ohio v. Kovacs, 105 S. Ct. 705, 711 n.12. See also id. $711-12$ ("[W]e do not question that anyone in possession of the site-whether it is Kovacs or another . . -must comply with the environmental laws of the state of Ohio. Plainly that person or firm may not ... refuse to remove the source of such conditions.").

183. Id. at 711 .

184. N.Y. Estates, Probate \& Trust Law $§$ 2-1.11(b) (McKinney 1981); Uniform Probate Code § 2.801 (1983). 
bankruptcy, why must the trustee abandon "to the debtor"? Also, the "gift" analogy contradicts the idea that the trustee takes property from the debtor as if the trustee were a hypothetical lien creditor. ${ }^{185}$ Lien creditors do not cut off the debtor's interest in property until there is a foreclosure sale and a termination of any redemption period. Nevertheless, some sort of ability of the debtor to refuse negative-value land would vindicate the debtor's fresh start, a policy that the Supreme Court sought to achieve in the Kovacs case. ${ }^{186}$ Perhaps, rather than drawing a fancy analogy, it would be better simply to declare that the debtor need not take back negative-value property that the trustee abandons.

b. Corporate bankruptcies. Abandonment of contaminated land to the corporate owner does not even appear to conflict with any federal fresh-start policies since a corporation has no right to a discharge in bankruptcy. ${ }^{187}$ Moreover, its shareholders are immune from toxic-waste liability. ${ }^{188}$ But if an insolvent corporation can be forced to dissolve under state law, ${ }^{189}$ who would own the contaminated land and inherit this servitude liability? State law sometimes provides that a corporation's shareholders are the lucky recipients of unclaimed property. ${ }^{190}$ Here, again, successor liability may play cruel tricks, for unless state law recognizes a right to refuse the "bequest" or prevents dissolution of the corporation, the stockholders could become landowners with successor liability for toxic-waste cleanup. ${ }^{191}$

To summarize, the Supreme Court has refused to allow the trustee to abandon contaminated land, at least in cases where the public health is imminently threatened by the toxic-waste contamination. When no

185. 11 U.S.C.A. \$ 544(a) (West Supp. 1985).

186. See supra text accompanying note 183 .

187. 11 U.S.C.A. \& 727(a)(1) (West 1979).

188. New Jersey imposes liability on majority shareholders of polluting corporations however. N.J. Stat. Ann. tit. 13, \$§ 13:1E-102, 13:1 E103 (West Supp. 1985); see Note, Abandoning Hazardous Waste Sites in Bankruptcy: Midlantic National Bank v. New Jersey Department of Environmental Protection, 13 Econ. L.Q. 555, 571 (1986).

189. Whether corporations can be dissolved by state attorneys general and on what grounds is somewhat uncertain. Some sort of fraud must be alleged. See generally H. Henn \& J. ALEXANDER, Laws of Corporations and Other Business Enterprises $\$ 348$ (3d ed. 1983).

190. Addy v. Short, 47 Del. 157, 162, 89 A.2d 136, 138-39 (1952); City of Klamath Falls v. Bell, 7 Or. App. 330, 340-42, 490 P.2d 515, 520 (1971). These cases dealt with entitlement to land reverting to a corporate owner after the corporation was dissolved. In $A d d y$ a receiver was appointed to sell the land and divide the proceeds, 47 Del. at 159-60, 89 A.2d at 137-38, while in Klamath Falls the court simply gave the land to the heirs of the shareholders, 7 Or. App. at 340-42, 490 P.2d at 520-21. While these cases involved land that had a positive value, courts will be tempted to apply the rule from these cases to those involving contaminated land on the theory that property rules should not change just because the land has a different value.

191. The EPA seems prepared to argue that CERCLA overrides state policies of limited liability. EPA Memorandum, supra note 71, at 2-10. The theory is that the CERCLA definition of "person," 42 U.S.C. $\$ 9601(21)$ (1982), includes shareholders of corporations that own toxic-waste facilities. The EPA Memorandum cites one unreported case in which this anti-shareholder theory was actually followed or at least approved. EPA Memorandum, supra note 71, at 4 (citing United States v. Northeastern Pharmaceutical \& Chemical Co., 80-5066-CV-S-4, Memorandum opinion at 37 (W.D. Mo. 1984)). But see Krivo Indus. Supply Co. v. Nat'l Distillers \& Chem. Corp., 483 F.2d 1098, 1102 (5th Cir. 1973) (ruling that analogous statutory language incorporated state policies of limited liability of shareholders), reh'g denied, 490 F.2d 916 (5th Cir. 1974). 
abandonment is possible, the government should receive an administrative priority for reimbursement (if for cleanup after bankruptcy occurs). When abandonment is possible (because the threat to the environment is not imminent), the trustee can turn high-priority cleanup into low-priority cleanup by abandoning the negative-value land. In cases in which the value of a bankrupt estate is exceeded by the cost of cleanup, abandonment is inevitable, in which case the servitude liability will be reimposed upon the discharged debtor. Accordingly, the Supreme Court (or Congress) ought to make clear that when the trustee abandons contaminated land, the individual debtor may refuse to reassume ownership. Since claims related to the debtor's ownership of contaminated land are not among those excluded from discharge in section 523 of the Bankruptcy Code, the federal policy of fresh start should relieve the owner of negative-value land of its associated servitude liability. ${ }^{192}$

4. Strategic Reactions by Failing Businesses. The preceding discussion has assumed that the debtor is a landowner at the precise time of bankruptcy. If he is merely a former owner at that time, his liabilities related to the land would be strictly personal. No servitude on the debtor's property would exist to justify a high bankruptcy priority for postbankruptcy cleanup expenses. Accordingly, the contingency of land ownership as a condition for servitude liability suggests an easy strategic reaction for the debtor: Simply convey away the contaminated land just prior to filing for bankruptcy. This tactic would be without purpose when the land has a positive value, but it might be highly tempting when the land has a negative value.

A rational, solvent grantee would obviously demand a payment reflecting the liability incurred by virtue of the conveyance. Since the payment should equal the claim the government would assert for cleanup costs, the landowner could gain nothing from such a transaction. The strategy works only if an insolvent grantee charges the grantor less than the full amount of the expected cleanup cost. This could occur if the grantee can hide the payment from his creditors. The limited liability of corporations is not the best refuge

192. At least as applied to state environmental laws, a good argument can be advanced for the proposition that federal supremacy requires that the debtor's toxic-waste liability be foreclosed in the interest of a fresh start. In Perez v. Campbell, 402 U.S. 637 (1971), the Supreme Court struck down a state law denying driving licenses to discharged bankrupts who had not fully paid personal injury judgments against them. This precedent supports the view that state-created toxic-waste servitudes should likewise be foreclosed. See Thomas Solvent Co. v. Kelley, 44 Bankr. 83, 86-87 (Bankr. W.D. Mich. 1984) ("Under Perez the court must first examine the primary purpose of the State environmental laws and the Federal Bankruptcy Code and then determine whether the state law is an obstacle to the effectuation of federal objectives") (citations omitted); Note, The Preemption of Bankruptcy-Only Exemptions, 6 CARDozo L. REv. 583, 587-90 (1985) (describing the scope of federal preemption in bankruptcy matters). Federal preemption, however, pits the entirety of federal law (both environmental and bankruptcy) against state law. Therefore, if a court were to find that federal environmental law forces debtors to take back negative-value land in spite of bankruptcy principles, state doctrines to that effect would not be inconsistent with the whole of federal law. Federal law does not allow a landowner to escape personal liability by abandonment, but this may not be the same as forcing debtors to accept the bankruptcy trustee's tender of contaminated land. See supra note 167. 
of a grantee. If the insolvent grantee were a holding corporation having no assets, the grantor would run an overwhelming risk of having the corporate veil pierced or even of being held liable for fraudulent conveyance. A better technique, therefore, would be for an individual to take the land in exchange for an under-the-table cash payment. There are thousands of judgment-proof individuals who are quite skilled at hiding from creditors by living a cash-only existence, and some of them could easily go into the business of title-holding. Organized crime syndicates should be able to locate and support individuals who can provide this service. ${ }^{193}$

The bankruptcy courts obviously need to develop a fraudulent conveyance doctrine to frustrate such conveyances, and statutory language probably can be made to fit the situation. ${ }^{194}$ A serious problem with a fraudulent conveyance approach, however, is that the trustee has no incentive to bring such an action, since if he wins, he impoverishes the bankrupt estate by creating a high-priority need to clean up the land. The government, therefore, will obviously have to take the initiative. Although most creditors are automatically stayed from pursuing such actions, ${ }^{195}$ the government is not automatically stayed if it is enforcing "a judgment, other than a money judgment, obtained in an action or proceeding by the governmental unit to enforce such governmental unit's police or regulatory power." 196 Once the government obtains the decree avoiding the conveyance, the trustee is stuck with the contaminated land and must clean it up pursuant to Midlantic National Bank.

This avoidance theory may seem awkward. Obviously, the cited statutes were never drafted with negative-value property in mind. Still, prebankruptcy conveyancing of burdened land to a judgment-proof person is an obvious abuse that someone will eventually be tempted to try, and courts should intervene to discourage the use of such subversive tactics, designed solely to avoid the effects of Midlantic National Bank.

5. Is Priority for Toxic-Waste Cleanup Costs a Bankruptcy Question? The direct connection between the unforecloseability of toxic-waste servitudes and the administrative-expense priority in bankruptcy for cleanup expenses, incurred by the trustee or the government, necessarily means that a federal bankruptcy rule will govern toxic-waste cleanup priority. In contrast, Douglas Baird and Thomas Jackson, separately and in a joint article, have characterized the question as a purely state law question with no independent bankruptcy component: If nonbankruptcy law provides the government with a statutory

193. I am indebted to Lynn LoPucki for pointing out this concern.

194. Section 7 of the Uniform Fraudulent Conveyance Act provides, "[e]very conveyance made ... with actual intent ... to hinder, delay, or defraud either present or future creditors, is fraudulent as to both present and future creditors." UNIFORM FRAUDULENT CoNVEYANCE ACT \& 7, 7A U.L.A. 509 (1985). Defrauded creditors (such as the EPA) may "[h]ave the conveyance set aside ... to the extent necessary to satisfy [its] claim." Id. \& 9(a), 7A U.L.A. 578 (1985).

195. In re MortgageAmerica Corp., 714 F.2d 1266, 1275 (5th Cir. 1983).

196. 11 U.S.C. \$ 362 (b)(5) (1982). 
lien, the government should be a secured creditor; if not, then the government should have the priority of only an ordinary general creditor. ${ }^{197}$ Baird now repeats this view in his contribution to this symposium. ${ }^{198}$

This view is wrongheaded. In only one situation could Baird and Jackson's view be valid: when the government has already expended funds to clean up before bankruptcy. ${ }^{199}$ If cleanup is prospective (or was prospective at the time of the bankruptcy), then cleanup should be an administrative expense with the highest priority. If this were not so, the trustee and the government would both have a strong incentive not to clean up and sell the contaminated land to a buyer who would. Although creditors would be more or less indifferent as between the two views, the subsequent delay could be harmful. ${ }^{200}$

Because of these incentives, a low-priority rule never makes sense when the value of the decontaminated land exceeds the expected cost of cleanup. It makes sense only in cases where the cost of cleanup exceeds the value of the decontaminated land, and even then, only if the trustee can abandon the land. ${ }^{201}$

The problem with looking to nonbankruptcy law for guidance in this matter is that conflicting norms emerge. Nonbankruptcy law usually tells us, on the one hand, that the environmental authorities have no lien, yet on the other hand, that they have rights against buyers of contaminated land.

197. Baird \& Jackson, Kovacs and Toxic Wastes in Bankruptcy, 36 Stan. L. Rev. 1199 (1984). Specifically, Baird and Jackson have suggested that in the Kovacs case, someone (other than themselves) should investigate Ohio law to see if the state had a lien for cleanup expenses. Id. at 1212-13. If this was found to be the case, then Ohio should have been a secured creditor; if not, they assume that Ohio had a general claim in bankruptcy without an administrative priority. Id. See also Kennedy, Creative Bankruptcy? Use and Abuse of Bankruptcy Law-Reflections on Some Recent Cases, 71 IowA L. REv. 199, 211 (1985).

For the record, Ohio law provides for a statutory lien under limited circumstances. The landowner and the director of the state department of environmental protection must have entered into a cleanup agreement. If such agreement is breached, the director may obtain a lien (on the contaminated land only) by notifying the county auditor that the landowner has breached his agreement. OHio Rev. CoDE \& 3734.23 (Supp. 1985).

In Kovacs, Ohio did not have any such statutory lien; but it did have a judicial lien by virtue of its receivership action against Kovacs's company, Chem-Dyne. In re Kovacs, 681 F.2d 454, 456 (6th Cir. 1982), vacated, 459 U.S. 1167 (1983). See OHIO Rev. Code $\$ 2735.01$ (C) (1981). This lien encumbers any property the receiver is authorized by the court to seize. Mine Safety Appliances Co. v. Best, 76 N.E.2d 108, 110-11 (Ohio Common Pl. 1947). Since the lien was at least five months old by the time Chem-Dyne filed for bankruptcy, it was not a voidable preference. See In re Kovacs at 454-56.

198. Baird, World Without Bankruptcy, supra note 116 , at 189

199. Even this is not true in New Jersey, which apparently has created a toxic-waste servitude for past cleanup liability. See supra text accompanying notes 66-75. In such a case, state law produces a servitude liability. For discussion of the difficulties in determining how this servitude status translates into ordinary lien priorities, see supra text accompanying notes 88-99.

200. It was argued earlier in this article that the creditors stand to gain if the trustee can choose the less expensive alternative as between cleaning up the land himself (at a high priority) and selling it to a buyer who would clean up. See supra text accompanying notes 137-41.

201. See In re T.P. Long Chem., Inc., 45 Bankr. 278, 286-87 (Bankr. N.D. Ohio 1985) (equating administrative priority for the government with no abandonment of the contaminated land); see also Baird \& Jackson, supra note 197, at 1201-02 (working hypothetical assumes contaminated land has no positive value). Professors Baird and Jackson do not discuss explicitly whether the trustee should have the power to abandon negative-value land. 
Consequently, nonbankruptcy law points simultaneously toward a low priority for cleanup costs in bankruptcy and a high priority as well. This indeterminacy virtually forces bankruptcy judges to resolve this problem on their own. ${ }^{202}$

Nor is it persuasive to criticize high priority to the government for cleanup costs because it will create an incentive for the government to push the debtor into bankruptcy. Baird writes,

[Alternatively,] Congress could pass a statute that gave the state priority in [bankruptcy, but nowhere else.] Such a statute, however, would make little sense. . . $[\mathrm{C}]$ reditors of a firm ... would in the future try to keep it out of bankruptcy, while the state would try to put it in. No one would have an incentive to ask the right questionwhich is whether a bankruptcy proceeding was the best place to sort out the affairs of a firm that was unable to meet all of its obligations. ${ }^{203}$

In this imagined strategic reaction of the government and other creditors, Baird has forgotten that the government has an injunctive remedy under the environmental laws. If the government obtains an injunction under state law, a debtor (if she fears imprisonment) will commence voluntary expenditures toward decontamination. Now it is the creditors who have an incentive to force a bankruptcy to prevent the debtor from "wasting" money on the environmental welfare of the public. If the focus is injunctive relief, a high priority in bankruptcy is needed to prevent creditors from interfering with the EPA's nonbankruptcy rights.

Similarly, a debtor may have signed a consent decree for cleanup. If a debtor chooses to be a good citizen and voluntarily perform the duties imposed by environmental law, creditors have an incentive to stop this conduct by filing bankruptcies. ${ }^{204}$ High priority in bankruptcy will stop the creditors from filing a bankruptcy solely to interfere with state law. ${ }^{205}$

202. In contrast, Baird assumes that state law does provide a determinate answer concerning creditor priorities. Baird, World Without Bankruptcy, supra note 116, at 189. A thorough review of the five anomalies produced by the clash of servitudes and liens, see supra text accompanying notes 87-98, however, should demonstrate this assumption to be wrong.

203. Baird, World Without Bankruptcy, supra note 116, at 189. At least three creditors must join in filing an involuntary petition in bankruptcy against a debtor who has twelve or more creditors. 11 U.S.C.A. \$ 303(b) (West Supp. 1986). Accordingly, in order to force a debtor into bankruptcy, the government would probably have to enlist the aid of two additional creditors, which should not be overly difficult.

204. In two recent cases, debtors entered into consent decrees outside of bankruptcy in which they promised to expend resources to clean up. Later, they filed for bankruptcy in an attempt to have the agreements dissolved. In both cases, the bankruptcy courts dismissed the petitions. In re Commercial Oil Serv., Inc., 58 Bankr. 311 (Bankr. N.D. Ohio 1986); In re Charles George Land Reclamation Trust, 30 Bankr. 918 (Bankr. D. Mass. 1983). In the manner of Jekyll-and-Hyde, the debtor at the time of the consent decree could be viewed as a socially responsible entity, while at the time of the filing of the bankruptcy petition, it could be viewed as the representative of the general creditors, who stood to lose if cleanup were undertaken. A high priority for cleanup by the government makes bankruptcy less desirable for the general creditors and will tend to render the antienvironmental bankruptcy tactic less effective. High priority could then achieve the same end as did the bankruptcy courts in the above-cited cases.

205. In Commercial Oil, the court specifically noted that the high priority of EPA injunctive claims would deplete the estate and cited this as a reason for its discretionary dismissal of the bankruptcy petition. In re Commercial Oil Serv., Inc., at 316-18. This suggests that high priority for the EPA discourages bankruptcies, rather than vice versa, as Baird supposes. 
In both the cases of injunctive relief and consent decrees, creditors have the incentive to force bankruptcies in order to prevent expenditures on cleanup. A high priority in bankruptcy would counteract this incentive. Therefore, Baird's proof that "incentives" are created by giving the EPA a priority is an irrelevant truism. Assuming the public pays attention to law at all, incentives are created no matter what choice is made. It is simply a matter of choosing between the incentives one thinks are to be preferred for their own sake. The incentive to clean up toxic wastes seems much to be preferred over the incentive to do nothing.

Furthermore, Baird has overlooked at least one social benefit that offsets the alleged social harm of encouraging the government to induce bankruptcies. The incentive for the government to put the debtor into bankruptcy, if it exists, creates increased risks for other creditors against which consensual creditors can protect themselves by charging higher interest rates. Since interest is part of the marginal cost of production, marginal toxicwaste-producing firms will be driven from the market, leaving the field to wealthier or more efficient firms, which are more likely to clean up efficiently. Limited liability is by its nature a legal rule that exports costs to the public. According high priority in bankruptcy to the government for cleanup costs, however, could compel toxic-waste-producing firms to internalize these costs more often. This positive effect should also be considered in assessing the desirability of a priority rule.

A final point must be made. The whole notion of isolating one bankruptcy rule and advocating its repeal because of the incentives it supplies is thoroughly illegitimate. The fallacy of such an exercise is illustrated by the following parable.

Suppose that creditor $A$ has a bankruptcy entitlement $A$ that is more attractive than $A$ 's parallel state-law right. In addition, suppose that creditor $B$ has a bankruptcy entitlement $B$ that is also more attractive than $B$ 's state-law right. Creditor $A$ would be better off if entitlement $B$ were repealed, and creditor $B$ would be better off if entitlement $A$ were repealed. Suppose that a law professor identifies entitlement $A$, and noting that it gives creditor $A$ an incentive to put the debtor into bankruptcy, he urges repealing entitlement $A$ on the grounds of efficiency.

The fallacy of this reasoning is that owing to the repeal of entitlement $A$, bankruptcies are made more likely than ever. Entitlement $A$ would have harmed creditor $B$, but now that creditor $B$ is no longer so threatened, he is relieved of restraint and is free to respond to the incentive supplied by entitlement $B$ to put the debtor into bankruptcy.

Economists call this the problem of the "second best," which states that what looks efficient in the abstract is actually inefficient because of other inefficiencies present in society. ${ }^{206}$ In order to make bankruptcy law

206. An excellent description of "second-best" problems can be found in Rizzo, The Mirage of Efficiency, 8 Hofstra L. Rev. 641, 645-48 (1980). 
completely neutral in its mediation among creditor claims, a radical revision of the Bankruptcy Code would be necessary to eliminate all incentives for or against bankruptcy that may exist. ${ }^{207}$ Second-best problems are inevitable, however; without a thorough review of all countervailing disincentives, suggestions for reform are equally likely to be self-defeating when put into practice and hence are completely illegitimate.

\section{Conclusion}

Successor liability generally produces inequalities between creditors who currently have claims and creditors who some day may have them. If we assume that creditors should be treated equally over time (barring some distributive norm to the contrary), it is necessary to consider foreclosure rules for successor liability in bankruptcy. This article advocates rejection of foreclosure rules for contractually created servitudes and suggests rules for the products-liability servitude. The toxic-waste servitude, however, has been a harder issue to resolve. Rather than suggest some solution, I have simply examined the implications of some Supreme Court dicta that suggest that no foreclosure of the servitude should be allowed when uncontaminated land values exceed the cost of cleanup. Where uncontaminated land values do not justify the cost of cleanup, the Supreme Court has held that at least in cases of environmental emergencies, the trustee should not be allowed to abandon negative-value land until the bankrupt estate has been depleted. The principles emerging from these rules indicate a high administrative-expense priority should be awarded for any cleanup that occurs after bankruptcy commences. If the trustee can abandon the land, one needs to consider to whom the land will be abandoned. Although a rule could be adopted here to vindicate the bankruptcy discharge of individual debtors, discharge of the debtor's personal toxic-waste servitude liability seems, nevertheless, to have been proscribed by the wide-ranging Kovacs dictum, effectively adding the toxic-waste servitude (where cleanup costs exceed the value of the bankrupt estate) to the list of nondischargeable debts enumerated by the Bankruptcy Code.

207. This is probably an impossible task, even theoretically. The concept of a state-law right as distinct from a bankruptcy right is certain to be indeterminate, leading to endless categorization squabbles. Complete neutrality of law is a dream. See Yablon, The Indeterminacy of the Law: Critical Legal Studies and the Problem of Legal Explanation, 6 Cardozo L. Rev. 917 (1985).

In my view, the "bankruptcy neutrality" position that informs most of the work of Baird and Jackson is completely incoherent, self-contradictory, and (as applied in their work) ad hoc. I set forth my objections to this doctrine in Carlson, Philosophy in Bankruptcy, 85 MICH L. REv. - (1987). 
